\title{
O ORDENAMENTO GERMÂNICO LONGOBARDO NOS SÉCULOS VII E VIII: A QUESTÃO DA TUTELA DAS MULHERES LIVRES NA CULTURA ITALIANA ALTO- MEDIEVAL
}

\author{
Alexandre Ribas de Paulo ${ }^{1}$ \\ Arno Dal Ri Júnior ${ }^{2}$
}

\begin{abstract}
RESUMO: O presente estudo se dedica à análise do discurso jurídico germânico-medieval nas fontes primárias que constituem as Leges Langobardorum, escritas nos séculos VII e VIII na Itália Alto Medieval, em busca da compreensão de possíveis mecanismos de tutela jurídica que versavam especificamente sobre as mulheres. O método utilizado é o indutivo e o meio de procedimento o histórico. O marco teórico adotado condiz com a arqueologia foucaultiana. Os resultados encontrados apontam que as mulheres da estirpe germânica no Reino Longobardo não estavam imersas em um imaginário místico e nem em situação de isonomia em relação aos homens, mas recebiam um tratamento amiúde com finalidades negociais pelos que detinham do poder de mundium sobre elas. Conclui-se que, com a maior influência do catolicismo nos reis da estirpe dos longobardos, houve um crescente incremento em normas que procuravam tutelar as vulnerabilidades das mulheres, seja diminuindo o rigor das punições ou protegendo seus interesses patrimoniais.
\end{abstract}

Palavras-chave: Mulheres. Tutela Jurídica. Reino Longobardo. Alta Idade Média. Leges Langobardorum.

\section{Introdução}

O objetivo do presente trabalho é apresentar os resultados de um estudo acerca dos possíveis mecanismos de tutelas jurídicas pertinentes às mulheres no âmbito das Leis dos Longobardos ${ }^{3}$, escritas entre os séculos VII e VIII na península itálica.

\footnotetext{
${ }^{1}$ Professor adjunto de Processo Penal na Universidade Estadual de Maringá - PR e Professor de Direito Processual Penal na Escola da Magistratura do Estado do Paraná, Maringá-PR. Doutor (2011) e Mestre (2006) em Direito, Estado e Sociedade pelo Programa de Pós-Graduação em Direito da Universidade Federal de Santa Catarina (PPGD/UFSC), com Pós-Doutourado pela mesma instituição. Instittuição: Universidade Estadual de Maringá, Paraná. Brasil. E-mail: ribasdepaulo@hotmail.com

${ }^{2}$ Professor de Teoria e História do Direito Internacional na Universidade Federal de Santa Catarina. Doutor em Direito pela Universidade Luigi Bocconi de Milão (2003) e mestre em Direito pela Universidade de Pádua (1999), com Pós-Doutorado pela Universidade Paris I (Panthéon-Sorbonne). Coordenador do Porgrama de Pós-Graduação em Direito da UFSC. Instituição: Universidade Federal de Santa Catarina. Brasil. E-mail: arnodalri@gmail.com

${ }^{3}$ No Brasil, muitas vezes é chamado de lombardo, que seria uma síncope da palavra longobardo, que designa o povo germânico que se instalou na Península Itálica a partir do século VI. Para ser coerente com as fontes primárias e, também, para evitar equívocos de nomenclatura que poderiam advir da palavra lombardo, que se refere aos naturais da região italiana setentrional denominada Lombardia, cuja capital é Milão, adota-se, no presente trabalho, apenas a palavra longobardo, cuja nomeação é específica à gens langobardorum, povo germânico que desenvolveu um reino autônomo na Itália entre os anos de 568 e 774 d. C.. Sobre o assunto, consultar (JARNUT, 2002). As
} 
Tendo como marco teórico o modelo proposto por Michel Foucault ${ }^{4}$, isto é uma "arqueologia"5 com uma descrição sistemática do próprio discurso jurídico medieval e com apoio em autores especialistas em historiografia medieval, adota-se o método indutivo (Cf. MEZZAROBA; MONTEIRO, 2004, p. 62; ALVES, 2002, p. 119; CERVO; BERVIAN, 1976, p. 68) e o meio de procedimento histórico ${ }^{6}$ com base em revisão bibliográfica, sobretudo em fontes primárias medievais para a compreensão da situação jurídica das mulheres no Reino Longobardo.

A relevância da pesquisa emerge devido à escassa produção acadêmica no Brasil dedicada às inúmeras culturas medievais com base em fontes primárias e, mormente quando se trata das condições jurídicas das mulheres na Idade Média, o anacronismo e descontextualização das informações genéricas formam imagens eventualmente distorcidas e pouco reais de como eram abordados os conflitos envolvendo pessoas que se encontravam em situações de vulnerabilidade perante sociedades germânicas eminentemente guerreiras e rurais no início do ocidente medieval. ${ }^{7}$

normas utilizadas no decorrer do texto foram traduzidas para uma versão inteligível em português - que não significa tradução literal -, tendo como lastro o próprio texto em latim e apoio na tradução para o italiano disponível na obra de Cláudio Azzarra e Stefano Gasparri (2005).

${ }^{4}$ Importante esclarecer que Michel Foucault não inaugurou um método específíco para o estudo do Direito Medieval e tampouco foi um historiador ou jurista medievalista. Assim, o objeto da presente pesquisa não é a análise do pensamento foucautiano sobre o Direito Medieval, até porque tal autor revelou amiúde que não dominava todos os matizes de tal período histórico. O que se utiliza do pensamento de Foucault é a "ferramenta de análise" que ele propôs, que é considerar o próprio discurso como prática. Como diz Paul Veyne (1998, p. 252): "Foucault não revela um discurso misterioso, diferente daquele que todos nós temos ouvido: unicamente, ele nos convida a observar, com exatidão, o que assim é dito. Ora, essa observação prova que a zona do que é dito apresenta preconceitos, reticências, saliências e reentrâncias inesperadas de que os locutores não estão, de maneira alguma, conscientes." Ainda sobre o marco teórico foucaultiano, consultar: (BURKE, 1992, p. 08-10) e (WOLKMER, 2007, p. 13-41).

${ }^{5}$ No sentido foucaultiano, a arqueologia visa “definir [...] os próprios discursos, enquanto práticas que obedecem as regras [...]; [definir] os discursos em sua especificidade; mostrar em que sentido o jogo das regras que utilizam é irredutível a qualquer outro" e, sobretudo, ela "não é o retorno ao próprio segredo da origem; é a descrição sistemática de um discurso-objeto." (FOUCAULT, 2000, p. 159-60).

${ }^{6}$ Sobre tal procedimento explica Antônio Manoel Hespanha (s.d., p. 07-08): “A história funciona - já se sugeriu - como um instrumento de crítica e de heurística. Como um instrumento de crítica ela revela o carácter epocalmente situado dos paradigmas políticos e jurídicos atualmente dominantes, nomeadamente, do 'estatismo' e o 'legalismo'. Como instrumento de heurística, ela sugere modelos alternativos de viver o direito e de o relacionar com outras 'tecnologias disciplinares', patenteando, também, as condições sociais, culturais e políticas de que dependem."

${ }^{7}$ O Reino Longobardo em muito se diferenciou da gênese do Reino dos francos, porquanto neste houve uma intensa comunhão entre os conquistadores germânicos, latifundiários galo-romanos e a elite eclesiástica na Gália, permitindo a manutenção de institutos administrativos romanos na região, ainda que de maneira simbólica. Ao revés, na Itália, centro do mundo na época do Império Romano, as categorias sociais mais influentes na administração política - como os senadores e bispos - foram exterminados pelos longobardos e houve a necessidade de quase um século de convivência entre germânicos e itálicos para que brotassem os primeiros sinais de união das etnias, fomentada pela conversão dos longobardos ao catolicismo, mas sem que o papa tivesse autoridade política e jurisdicional em relação aos súditos longobardos. Dessarte, as peculiaridades da administração política verificadas no Reino dos francos entre os séculos V e VIII não podem ser enxertadas, sem o cometimento de um enorme equívoco histórico, na Itália longobarda. E isso se aplica inclusive em relação às experiências jurídicas. Por outro lado é importante esclarecer que em 652 d.C, na Península Ibérica, foi editado o Código Visigótico, e como explica Augusto F. G. Thompson (1976, p. 29-30), era conhecido como Código de Chindasvindo. Explica o autor que com as alterações posteriores, foi "[...] chamado, indiferentemente, Codex Legum, Lex Visigotorum, Liber Legis Goticae, Forum Judicum, Liber Judicis, Lex Visigotorum Recesvindiana, e, 
Neste sentido, a presente pesquisa busca entender se as mulheres da estirpe longobarda ${ }^{8}$ eram ou não vistas como objetos de controle e punição por parte de uma sociedade germânica no início da Idade Média na Península Itálica. E, em caso negativo, se possuíam autonomia no âmbito jurídico.

Essa dúvida surge devido a algumas especulações, sejam elas literárias ou até acadêmicas, que instigam a ideia de que haveria uma certa isonomia das mulheres em relação aos homens nas sociedades germânicas no início do medievo ocidental e que, com a paulatina cristianização dos povos conquistadores do mundo romano, a visão misógina proveniente de um pensamento patriarcal deu azo ao conhecido episódio de "caça às bruxas". ${ }^{9}$ Nessa perspectiva, argumenta Rose Marie Muraro:

Do terceiro ao décimo séculos, alonga-se um período em que o Cristianismo se sedimenta entre as tribos bárbaras da Europa. Nesse período de conflito de valores, é muito confusa a situação da mulher. Contudo, ela tende a ocupar lugar de destaque no mundo das decisões, porque os homens se ausentavam muito e morriam nos períodos de guerra. Em poucas palavras: as mulheres eram jogadas para o domínio público quando havia escassez de homens e voltavam para o domínio privado quando os homens reassumiam o seu lugar na cultura. (KRAMER; SPRENGER, 2004, p. 13)

após a versão do latim impuro em que era originalmente vazado para o espanhol, Fuero Juzgo [...]”. Diversas das longobardas, as normas Visigóticas do século VII eram aplicadas a toda a população do Reino dos Visigodos. Nessa perspectiva, o mesmo autor (Idem) explica: "O Forum Judicum dá reconhecimento legal à interpenetração, provavelmente muito desenvolvida, entre as populações visigoda e romana. Admitindo expressamente o casamento entre membros das duas raças e atribuindo-se exclusividade no campo legislativo (a Constituição 8, Título I, Livro 29, proíbe a aplicação de quaisquer leis estranhas), consagrava, definitivamente, um direito geral e único para todo o povo." Sobre o assunto, também consultar Nilo Batista (2002) e Paulo Merêa (1948). Adriano Cavanna (2007, p. 5) pondera que minuciosos estudos revelaram significativas aproximações entre a legislação longobarda e outras normas compiladas por povos germânicos e que as mais fortes coincidências de institutos jurídicos se encontram no modelo legislativo visigótico. Contudo, salienta Bognetti (1966, p. 41) que as fontes históricas não revelam elementos que poderiam comprovar eventuais vínculos jurídicos dos longobardos com o Reino Visigótico nos séculos VI e VII, visto que restou somente uma carta do rei visigodo Sisebuto para Teodolinda e Teobaldo, escrita entre 616 e 620, tratando de assuntos vinculados ao catolicismo e à heresia católica e não de assuntos jurídicos. Essa informação também está presente em Tamassia (1889, p. XI).

${ }^{8}$ Nas normas longobardas são tratadas de diferentes pessoas, sendo que amiúde aparecem os servos e os aldios, que seriam os "semi-livres". Nas palavras de Cláudio Azzarra e Stefano Gasparri (2005, p. 117-8): "L'aldio è un semilibero, capace di possedere e di prendere iniziative economiche, ma tenuto a vivere sotto il patronato di un libero: cfr. Roth. 235. Il liberto è il servo che è stato affrancato." Quanto a essas pessoas, as normas fazem distinções entre servos e servas e aldios e aldias. Contudo, para fins da compreensão da situação das mulheres no Reino Longobardo, serão consideradas somente as situações jurídicas envolvendo as mulheres da estirpe germânica e não as de outras pessoas reguladas pelas normas estudadas.

${ }^{9}$ Como pondera Willian Carroll Bark (1979, p. 06): “Apesar de todos os esforços dos medievalistas para desfazer nas últimas décadas o mal causado pelos autores que usavam óculos de diferentes cores, tem sido extremamente difícil persuadir o mundo moderno a considerar o período medieval sem noções preconcebidas." 
Serão exploradas, portanto, as normas jurídicas escritas nos séculos VII e VIII que se referem às mulheres $\operatorname{livres}^{10}$, buscando compreender como que eram tutelados os interesses jurídicos delas na sociedade medieval dos longobardos. Tentar-se-á, então, elaborar uma resposta à problemática aventada, qual seja, se as mulheres eram concebidas por aquela cultura jurídica como sujeitos de direito munidos ou não de autonomia e de isonomia jurídica. ${ }^{11}$

\title{
2 As mulheres no Edito de Rotário
}

\begin{abstract}
${ }^{10} \mathrm{O}$ protagonismo feminino nas lendas que compõem o imaginário longobardo emerge já naquela que narra o início do seu processo migratório para a parte setentrional da Europa. Registrada em um texto do século VII denominado Origo gentis langobardorum (PAULO, 2009), conta a saga dos winnili, grupo de jovens de uma tribo que decidiram migrar de uma ilha chamada Scadanan sob o comando de dois chefes irmãos - Agio e Ybor - e de sua genitora Gambara. A saga narra que após o prenúncio de um embate do winnili com os vândalos, os chefes desta outra estirpe de guerreiros germânicos teriam rogado ao Deus Wotan para lhes conceder a vitória, sendo que este lhes teria respondido: "Quos sol surgente antea videro, ipsis dabo victoria". [Aqueles que eu vir por primeiro ao surgir do sol, a eles eu concederei a vitória]. Por sua vez, a matriarca Gambara e seus dois filhos teriam ido pregar a Frea, esposa de Wotan, e teriam lhe pedido o apoio de seu marido para obter a vitória na batalha. Então Frea sugeriu-lhes que as mulheres deveriam comparecer, com seus cabelos em volta da face, à semelhança de uma barba, acompanhadas de seus maridos guerreiros, ao surgir do sol. Quando este apareceu, Frea girou o leito em que repousava Wotan e fez com que seu rosto ficasse virado para o oriente e o despertou. O Deus guerreiro, ao acordar, viu primeiro os winnilis e suas mulheres com os cabelos soltos entorno da face e disse: "Qui sunt isti longibarbae" [Quem são aqueles de longas barbas?]. E Frea lhe respondeu: "Sicut dedisti nomen, da illis et victoriam". [Assim como lhes deste um nome, dê-lhes também a vitória]. Então Wotan lhes deu a vitória e " $A b$ illo tempore winnilis langobardi vocati sunt". [Desde aquele tempo os winnilis são chamados de Longobardos.] $\mathrm{O}$ papel enigmático das mulheres na construção de identidade de um grupo guerreiro germânico na antiguidade (Cf. GASPARRI, 1997, p. 72-3) emerge com força nesta narrativa, diferenciando-se, por exemplo, da mitologia romana - em que a nutriz seria uma loba e as mulheres lendárias surgem no episódio conhecido como "rapto das sabinas". Paolo Diácono (2008, p. 22), em sua obra Historia Langobardorum, escrita no século VIII e em um ambiente europeu já dominado pelo cristianismo católico, teceu críticas à versão mitológica de sua estirpe ao exclamar que os pedidos de vitória que teriam sido elaborados pelos vândalos e pelos winnilis a Wotan seriam "ridiculam fabulam", e afirma (Ibidem, p. 24) que "Certum tamen est, Langobardos ab intactae ferro barbae longitudine, cum primitus Winnili dicti fuerint, ita postmodum appellatos. Nam iuxta illorum linguam lang longam, bard barbam significat". [É certo porém que os longobardos, que antes eram ditos winnilis, foram chamados assim em um segundo momento pelo tamanho das barbas jamais tocadas pela lâmina]. Dessa forma, parece que o historiador medieval teria refutado a influência das mulheres nos destinos da estirpe e justificado que o nome seria decorrente de uma característica eminentemente masculina, que seriam as barbas. No cenário político, é importante mencionar que no século VI, quando os longobardos chegaram para conquistar a Península Itálica, a grande maioria deles ainda eram pagãos adoradores de Wotan e os convertidos ao cristianismo eram hereges arianos, o que causava repúdio aos cristãos locais e polêmicas com o clero católico do Ocidente. Nesse cenário é que surgiu a rainha Teodolinda (570-628), que é considerada a principal responsável pela conversão dos longobardos à fé católica. Como registrou Paolo Diacono (Ibidem, p. 172): "Regina vero Theudelinda quia satis placebat Langobardis, permiserunt eam in regia consistere dignitate, suadentes ei, ut sibi quem ipsa voluisset ex omnibus Langobardis virum eligeret, talem scilicet qui regnum regere utiliter possit”. [Quanto à rainha Teodolinda, porque agradava muito aos Longobardos, estes lhe permitiram de manter a dignidade régia, convidando-a a escolher entre todos os Longobardos o esposo que quisesse: obviamente um que pudesse ser útil ao reino.] Ela escolheu para marido Agilulfo, Duque de Turim, e o relacionamento entre o Reino Longobardo e o papado foi revelado por algumas epístolas, das quais o pontífice elogiava as atitudes do rei longobardo (Agilulfo) em relação à paz nos campos, além de pedir apoio à rainha para manter o marido no caminho da paz. Nessa perspectiva, pode-se notar que foram figuras femininas que intercederam no campo místico do povo longobardo, tanto na mitologia pagã quanto no início do século VII quando os germânicos considerados "bárbaros" foram sendo cada vez mais cristianizados e, finalmente adotaram o catolicismo, tornando-se um povo típico do ocidente medieval.

11 Para uma visão geral da construção mística sobre o papel das mulheres na Alta Idade Média, mas constextualizado no Reino Franco, consultar: (ROUCHE, 2004, p. 464-5).
\end{abstract}


Foi Rotário ${ }^{12}$ o autor do Edito de 22 de novembro de 643, que leva o seu nome e conta com 366 capítulos (artigos), escritos em latim ${ }^{13}$. Estes últimos podem ser divididos genericamente, considerando a matéria jurídica tratada, em nove grupos (CALASSO, 1954, p. 107): I) ilícitos políticos e militares (1 a 14); II) ilícitos contra as pessoas (15-145); III) ilícitos concernentes à destruição de edificações (146-152); IV) direito de família e sucessões (153-226); V) direitos das coisas (227-244); VI) direito das obrigações (245-252); VII) ilícitos de menor ofensa e danos (253358); VIII) procedimentos (359-366); IX) matérias diversas, complementando os capítulos anteriores (367-388).

Da leitura da norma é possível constatar a existência de quarenta e quatro capítulos tratando das mais variadas situações jurídicas envolvendo diretamente mulheres livres pertencentes ao grupo. Desses, vinte e três capítulos tratam das regulamentações jurídicas patrimoniais; nove estipulam punições específicas às mulheres por suas condutas e doze mencionam uma suposta proteção a elas.

A situação jurídica em que se encontravam as mulheres longobardas na primeira metade do século VII, contudo, como salienta Francesco Calasso (Ibidem, p. 248), não comporta a liberdade plena, como chegaram a possuir as romanas. Nesse caso, o termo jurídico mundium significava a necessidade de a mulher sempre estar submetida ao arbítrio de um parente do sexo masculino - ou ao rei -, inclusive em relação à disponibilidade dos bens, como deixa claro o capítulo 204:

204. Nulli mulieri liberae sub regni nostri ditionem legis langobardorum viventem liceat in sui potestatem arbitrium, id est selbmundia, vivere, nisi semper sub potesta tem virorum aut certe

\footnotetext{
${ }^{12}$ Rotário, duque da Brescia, tornou-se rei eleito em 636, passadas seis décadas da chegada dos longobardos na Itália. Como era cristão ariano, aproveitou para consolidar a política de tolerância religiosa em sua época entre católicos e os ainda longobardos pagãos - tanto que se casou, para fins de legitimação régia, com a viúva do rei Ariovaldo, Gundeperga, que era filha da rainha Teodolinda. (Cf. DIACONO, 2008, p. 224; BOGNETTI, 1966, p. 312-17; SESTAN, 1994, p. 258-70)

${ }^{13} \mathrm{Na}$ sua grande maioria constituída por pessoas analfabetas (BOGNETTI, 1967, p. 129), a Gens Langobardorum que incursionou na Itália era até então regida por normas de direito consuetudinário praticadas pelos antepassados, conhecedores dos mecanismos de resolução de conflitos tradicionais de seu povo. Deveriam, os súditos, estar pugnando às potestades da época pela sua continuidade, em oposição a possíveis alterações dos costumes por parte de alguns duques, que, segundo exegese do próprio Edito de Rotário, estariam arruinando os pobres, possivelmente tratando os seus comandados com poderes de autoridade militar nos assuntos da vida civil, o que seria contrário ao velho costume germânico de paridade entre os guerreiros livres. Do prólogo do Edictum Rothari: "Quanta pro subiectorum nostrorum commodo nostrae fuit sollicitudinis cura, et est, subter adnexa tenor declarat; precipue tam propter adsiduas fatigationes pauperum, quam etiam superfluas exactiones ab his qui maiore virtute habentur; quos vim pati cognovimus. Ob hoc considerantes dei omnipotentis gratiam, necessarium esse prospeximus presentem corregere legem, quae priores omnes renovet et emendet, et quod deest adiciat, et quod superfluum est abscidat. In unum previdimus volumine conplectendum, quatinus liceat unicuique salua lege et iustitia quiete vivere, et propter opinionem contra inimicos laborare, seque sousque defendere fines. [...]".
} 
regis debeat permanere; nec aliquid de res mobiles aut inmobiles sine voluntate illius, in cuius mundium fuerit, habeat potestatem donandi aut alienandi. ${ }^{14}$

O mundium, conforme o capítulo 161, que trata da sucessão hereditária, poderia ser exercido por vários homens ao mesmo tempo, sendo calculado mediante proporção entre os familiares legitimados: "De mundio inter legitimos et naturales. Si fuerint filii legitimi et filii naturales et sorores tam legetimas quam naturales, pro mundio earum tollant legitimi filii partes duas, naturales vero partem tertiam." 15

Com a leitura do Edito de Rotário, essa tutela cogente parece ser causada pela ideia de que somente os homens teriam força e as mulheres, ao revés, não estariam incluídas nas virtudes guerreiras, como revelam os capítulos 278 e 378 do Edito:

278. De hoberos, id est curtis ruptura. Mulier curtis rupturam facere non potest, quod est hoberos; absurdum videtur esse, ut mulier libera, aut ancilla, quasi vir cum armis vim facere possit.

378. Si mulier libera in scandalum cocurrerit, ubi viri litigant, si plagam aut feritam factam habuerit aut forsitan inpincta fuerit aut occisa, adpretietur secundum nobilitatem suam et sic conponatur, tamquam si in fratrem ipsius mulieris perpetratum fuisset; nam alia culpa pro iniuria sua, unde nongenti solidi iudicantur, non requiratur, eo quod ipsa ad litem cocurrit, quod inhonestum est mulieribus facere. ${ }^{16}$ (sem grifos no original)

Com efeito, a noção geral que se extrai do Edito de Rotário é que o tratamento concedido às mulheres não reconhecia às mesmas os institutos jurídicos equiparados aos homens livres. Ao contrário, as relações jurídicas estabelecidas por elas eram contempladas como pertencentes ao patrimônio dos homens - detentores do seu mundium, transmissível mediante contrato de casamento. ${ }^{17}$ Do complexo de normas se extrai as seguintes regulamentações:

\footnotetext{
${ }^{14}$ Tradução livre: "204. A nenhuma mulher livre que viva sobre a jurisdição do nosso reino segundo a lei dos longobardos seja consentido viver sob o arbítrio do próprio poder, isto é, selpmundia, mas, ao contrário, deve sempre permanecer sob o poder dos homens ou do rei; e não tenha a faculdade de doar ou alienar qualquer dos bens móveis ou imóveis sem o consentimento daquele em cujo mundium se encontra."

${ }^{15}$ Tradução livre: "161. Do mundium entre os legítimos e naturais. Se há filhos legítimos e naturais e irmãs, sejam legítimas ou naturais, pelo mundium destas os filhos legítimos recebam dois terços, aqueles naturais um terço."

${ }^{16}$ Tradução livre: "278. Do hoberos, isto é, da violação da corte. Uma mulher não pode violar a corte, que é o hoberos, parece absurdo que uma mulher livre ou uma serva possa fazer uma ação de força com as armas como um homem. [...] 378. Se uma mulher livre acorrer em um tumulto, onde os homens estão brigando, se recebe uma lesão ou ferida ou até se vier a ser batida ou morta, seja avaliada segundo a sua nobreza e assim seja paga a composição, como se fosse cometido o fato contra o irmão da mulher; mas não se reclame alguma outra culpa pela ofensa, pela qual são estimados novecentos sólidos, porque ela mesma acorreu na briga, o que é desonroso para uma mulher fazer."

${ }^{17}$ Chama a atenção, por outro lado, que as interpretações dadas por Michel Rouche (2004, p. 450) a respeito do mundium exercido pelos germânicos francos, de acordo com a Lex Salica (século V), comporta uma interpretação distinta - e um tanto romantizada - das que exsurgem da análise do discurso das fontes primárias dos longobardos:
} 
165. Si quis dixerit de uxorem alienam, quod mundius ad ipsum pertineat, nam non ad maritum, tunc ille, qui eam habet uxorem, preveat sacramentum cum legitimos sacramentales suos duodicem, quod de certo domino mundium ipsius fecisset, et non eum alteri per legem dimittere debeat; si hoc fecerit, habeat et fruatur. Quia iniustum videtur esse, ut tam grandis causa sub uno scuto per pugna dimittatur.

180. Si puella sponsata lebrosa apparuerit. Si contigerit, postquam puella aut mulier sponsata fuerit, lebrosa aut demoniaca aut de ambos oculos excecata apparuerit, tunc sponsus recepiat res suas et non conpellatur ipsam invitus tollere ad uxorem, nec pro hac causa calomnietur: quia non suo neclicto dimisit, sed peccatum eminente et egritudine superveniente.

188. Si puella libera aut vedua sine volontatem parentum ad maritum ambolaverit, libero tamen, tunc maritus, qui eam accepit uxorem, conponat anagrip solidos viginti et propter faida aliûs viginti; et si contegerit eam antea mori, quam mundium eius faciat, res ipsius mulieris ad eum revertantur, qui mundium eius in potestatem habit; nam amplius calumnia praesumptori non generetur: ideo perdat maritus res mulieris, eo quod mundium facere neglexit.

214. Si quis liberam puellam absque consilio parentum aut voluntate duxerit uxorem, conponat, ut supra, anagrift solidos XX et propter faida alios vigenti. De mundio autem, qualiter convenerit et lex habet; sic tamen, si ambo liberi sunt. ${ }^{18}$

As demais regulamentações patrimoniais também condizem, em sua maioria, ao casamento, ou seja, um negócio jurídico tratado entre os homens e que pouco revertia em vantagens para as mulheres, como surge da exegese do capítulo 181, do Edito: "De nuptiis. Si pater filiam suam aut frater sororem legetimam alii ad maritum dederit, in hoc sibi sit contempta de patris vel matris

\footnotetext{
"Assim, a família é grande para proteger, mas para se perpetuar precisa das mulheres. Ora, já o vimos, o homem, chefe de parentela ou de linhagem, é proprietário do mund de seus filhos, pois é guardião da pureza do sangue e da autenticidade da descendência. Passará esse poder protetor às mãos do marido através do casamento, ou, mais exatamente, do noivado, que constitui menos uma lembrança da antiga compra da mulher pelo futuro esposo que um penhor de segurança contra a violência e um certificado de garantia da pureza da noiva. Na cerimônia de noivado os pais recebem uma certa quantia, compra simbólica do poder paterno sobre a moça.”

18 Tradução livre: "165. Se alguém diz da mulher de outro que o mundium concerne a ele e não ao marido, então aquele que tem a mulher preste juramento com doze juramentadores de ser o indiscutido detentor do mundium dela e de não dever deixá-lo por lei a outro; se faz assim, possua e usufrua. Porque parece injusto que uma causa tão importante seja resolvida sob um escudo, com um duelo. [...] 180. Se uma jovem prometida em casamento aparece leprosa. Se acontece que uma jovem ou uma mulher, depois de ser prometida como esposa, mostrar-se leprosa ou endemoninhada ou cega dos dois olhos, então seu promitente esposo resgate seus bens e não seja constrito a pegála como mulher contra sua vontade, nem seja caluniado por esse motivo, porque não a abandonou por sua própria negligência, mas por um pecado evidente e por uma superveniente doença. [...] 188. Se uma jovem livre ou uma viúva, contra a vontade dos parentes, toma por marido, desde que seja homem livre, então o marido que a tomou por mulher pague como composição por anagrip vinte sólidos e outros vinte pela faida. Se acontece que ela morra antes que ele adquira o seu mundium, os bens dela retornarão àqueles que possuem o poder de seu mundium e não se produza mais nenhuma acusação de indébito contra o usurpador; perca portanto, o marido, os bens da mulher, do momento em que negligenciou a aquisição do mundium. [...] 214. Se alguém toma como mulher uma jovem livre contra a vontade dos parentes, pague, como acima, como composição pelo anagrift vinte sólidos e outros vinte pela faida. No que concerne ao mundium, segundo quanto convém e a lei prevê, assim como pacto que há entre livres."
} 
substantia, quantum ei pater aut frater in diae traditionis nuptiarum dederit, et amplius non requirat." 19

Típicos do casamento longobardo, alguns institutos jurídicos são emblemáticos deste contexto, entre eles: I) meta; II) morgingab; III) metfio; e IV) faderfio.

O primeiro seria o valor pago pelo pretenso marido ao detentor do mundium da mulher como uma contrapartida pecuniária pelo recebimento da mesma. Como salientam Cláudio Azzarra e Stefano Gasparri (2005, p. 121): "Essa viene stabilita per convenientiam all'atto degli sponsali e poi data all'atto della traditio della donna nella casa del marito; [...]".

O segundo "è il dono dato dal marito alla moglie il mattino dopo le nozze, in segno di onore e di soddisfazione." (Ibidem, p. 122)

$\mathrm{O}$ terceiro corresponde aos bens prometidos pelo pretenso marido à noiva $\mathrm{e} o$ último seriam os bens doados pelo pai ou irmão quando a mulher contraísse o casamento. Esses institutos podem ser facilmente compreendidos nos capítulos 178 e 199, do Edito de Rotário:

178. De sponsalibus et nuptiis. Si quis sponsaverit puellam liberam aut mulierem, et post sponsalias factas et fabola firmata duo annûs sponsus neclexerit eam tollere et di lataverit nuptias exequi: post transactum biennium potestatem habeat pater aut frater, vel qui mundium eius potestatem habet, distringere fideiussorem, quatinus adinpleat metam illam, quae in diae sponsaliorum promisit: postea leciat eos ad marito alii da re, libero tamen. Et meta quae exacta fuerit, sit in potestatem puellae aut mulieris, eo quod sponsus intra prefenitum tempus uxorem accepere neclexit aut si volontariae dilatavit, excepto inevitavele causa.

199. Si vidua in domo patris regressa fuerit. Si pater filiam suam aut frater sororem ad maritum dederit et contigerit casus, ut ille maritus moriatur, et pater aut frater mundium eius liberaverit, sicut supra constitutum est, et illa in domo patris aut fratris regressa fuerit et alias sorores in casa patris aut fratris invenerit, et postea pater aut frater mortuos fuerit, et illa remanserit in domo cum alias sorores una aut plures, et ad facultatem patris aut fratris venerint dividendam cum aliûs parentes aut curtem regis: tunc illa vidua, qui in domo patris aut fratris regressa est, habeat sibi in antea morgingab et metfio. De faderfio autem, id est, quantum de alia dona, quando ad maritum ambulavit, pater aut frater ei dedit, mittat in confuso cum alias sorores. Et illa alia soror, una aut plures, tollant unaquisqua in antea tantum, quantum pro mundium pater aut frater liberandum ad parentes mariti defuncti dedit. Reliqua patris vel fratris substantia aequa lanciae dividant, sicut in hoc edictum legitur. Et si sola in casa remanserit, in quantum ei per legem conpetit, heres succedat. ${ }^{21}$ (sem grifo no original)

\footnotetext{
19 Tradução livre: “181. Das núpcias. Se um pai dá como esposa para outro a própria filha, ou o irmão a irmã legítima, ela se contente com a quantidade de bens que o pai, ou a mãe e pai, ou o irmão, lhe deram no dia em que foi dada como mulher e não reclame mais."

${ }^{20}$ Michel Rouche (2004, p. 452) interpreta o instituto jurídico, entre os germânicos estabelecidos na Gália, da seguinte maneira: "Mas o importante continua sendo, na manhã seguinte às bodas, a doação suplementar que o marido faz à jovem esposa, a morgengabe. É atestada tanto entre os francos como entre os borgúndios. Trata-se de um agradecimento do marido por havê-la encontrado virgem e, portanto, de uma garantia de que as crianças que ela dará à luz serão realmente dele. A doação atesta a pureza do sangue da esposa."

${ }^{21}$ Tradução livre: “178. Dos esponsais e das núpcias. Se alguém contrai os esponsais com uma jovem ou uma mulher livre e depois de ter contratado os esponsais e ter firmado o acordo o promitente esposo, por dois anos,
} 
Observa-se, assim, que apesar das mulheres estarem sempre vinculadas a um homem, elas poderiam ter bens particulares e, dependendo da origem dos mesmos, esses permaneceriam com elas até a sucessão hereditária. Estariam, contudo, sempre sob o controle de quem possuíssse seu mundium. Para ilustrar as particularidades que envolviam os institutos longobardos em relação à tutela das mulheres e a relação com o patrimônio próprio, o capítulo 182 estabelece as prerrogativas das viúvas:

\begin{abstract}
182. De vidua, qualem habeat licentiam. Si quis filiam suam aut quamlibet parentem in coniugium alii dederit, et contegerit casus, ut ille maritus moriatur, potestatem habeat illa vidua, si voluerit, ad alio marito ambolandi, libero tamen. Secundus autem maritus, qui eam tollere disponit, de suis propriis rebus medietatem pretii, quantum dictum est, quando eam primus maritus spunsavit, pro ipsa meta dare debeat ei, qui heres proximus mariti prioris esse invenitur. Et si noluerit accepere, habeat ipsa mulier et morgingab et, quod de parentes adduxit, id est faderfio: parentes vero eius potestatem habeant eam dandi ad alium maritum, ubi ipsi et illa voluerint. Et mundium eius prioris mariti parentes non habeant pro eo, quod ei denegaverunt volontatem suam; ideo redeat mundium eius ad proximûs parentes, qui prius eam ad maritum dederunt. Et si parentes non fuerint legitimi, tunc mundius ille ad curtem regis perteneat. Et si tales fuerit mulier, quae maritum non vellit aut non possit habere, sit in potestatem illius, ad quem mundius de ea pertenit. Et si ipse eam male habuerit aut tractaverit, et probatur, tunc liceat eam ad parentes suos reverti; et si parentes non habuerit, tunc ad curtem regis habeat refugium, et mundium eius sit in potestatem regis.
\end{abstract}

Por outro lado, os presentes de casamento dados à mulher ficariam com o marido, como explicita o capítulo 184: "De exenio nuptiali. Si quando pater filiam suam aut frater sororem suam alii ad uxorem tradederit et aliquis ex amicis, accepto exenio, ipsi mulieri aliquid dederit, in ipsius

negligencia de tê-la e retarda a conclusão das núpcias, transcorridos os dois anos, o pai ou irmão ou aquele que detém o mundium dela tenha a faculdade de constranger aquele que deu a garantia para satisfazer aquela meta que havia prometido no dia dos esponsais; e depois seja consentido a eles dá-la para outro marido, contanto que seja livre. A meta recolhida permaneça em poder da jovem ou da mulher, porque o promitente esposo negligenciou de tê-la como mulher entre o período prescrito, ou se deliberadamente retardou, a menos que o fez por uma causa inevitável. [...] 199. Se uma viúva retorna para casa paterna. Se um pai dá a própria filha como mulher, ou um irmão a irmã, e o acaso quer que o marido morra e o pai, ou o irmão, resgata o seu mundium, como estabelecido supra, e a fazem retornar para a casa do pai ou do irmão e encontra na casa do pai, ou do irmão, outra irmã; e depois o pai, ou o irmão, morre e aquela permanece na casa com as outras irmãs, uma ou mais, e se junta à divisão das coisas do pai, ou do irmão, com outros parentes ou a corte real, então a viúva, que retornou à casa do pai, ou do irmão, tenha doravante para si o morgingab e a metfio. Mas a respeito do faderfio, isto é quanto aos outros bens doados pelo pai ou o irmão que lhe deram quando tomou o marido, coloque-os em comum com a outra irmã. E as irmãs, uma ou mais, peguem cada uma para o futuro tanto quanto o pai, ou o irmão, tinham dado aos parentes do marido morto para resgatar o mundium. Os restantes bens do pai, ou do irmão, sejam divididos em partes iguais, como se lê neste Edito. E se permanece sozinha na casa, suceda como herdeira na quantidade que lhe concerne por lei." 
sit potestatem, qui mundium de eam fecit; eo quod maritus, si launegild requisitum fuerit, ipse debet solvere. ${ }^{22}$

Os demais capítulos que tratam do casamento longobardo regulam, por exemplo, o caso em que a noiva é acusada de adultério e que, se não provada a acusação, o nubente deve honrar o contrato de casamento ou pagar o dobro da meta aos parentes (capítulo 179) e a morte do noivo que já teria pago a meta, caso em que os herdeiros dele resgatariam metade do valor já pago (capítulo 183).

Nos capítulos 188, 190, 191 e 192, são tratadas situações em que ocorreria ilicitude na contratação do casamento, como a mulher contrair marido sem consentimento do possuidor de seu mundium; promessa de casamento de uma mulher já prometida a outrem; rapto de esposa prometida a outrem e fraude no ajuste do casamento por parte dos possuidores do mundium. Todas essas situações seriam resolvidas com o pagamento de uma composição em quantias fixadas em solidus ${ }^{23}$ por parte do responsável pelo ato ilícito aos homens que seriam, portanto, os ofendidos pela ilegalidade.

Quanto à sucessão hereditária envolvendo as filhas, os capítulos 158 e 159 estipulam que as mulheres não poderiam herdar a totalidade dos bens do pai falecido. O capítulo 160, por sua vez, também disciplinou os quinhões hereditários e, da mesma forma que o capítulo 161 - já referido , estabeleceu a proporção do mundium sobre as mulheres:

158. Si quis dereliquerit filiam legitimam unam et filium naturalem unum aut plures et alios parentes proximos aut heredis, aequaliter dividant substantiam defuncti, id est in tres partes: filia legitima accipiat uncias quattuor, quod est tertia pars; naturalis filii uncias quattuor, quod est tertia pars, et parentis proximi aut heredis uncias quattuor, id est tertia pars. Et si parentes proximi non fuerint, tunc curtis regia suscipiat ipsas quattuor uncias.

159. Si quis dereliquerit filias legitimas duas aut pluris, et filiûs naturalis unum aut plures, et alios parentes proximos, ut supra: illas filias tollant uncias sex, quod est medietas; naturalis filii uncias quattuor, quod est tertia pars; et parentes legitimi uncias duas, quod est sexta pars; et si parentes non fuerint, curtis regia ipsas duas uncias suscipiat.

\footnotetext{
${ }^{22}$ Tradução livre: "184. Do presente de núpcias. Se, quando o pai entrega a própria filha como mulher para outrem, ou um irmão a própria irmã, qualquer dos amigos dá um presente à mulher, fique em poder daquele que adquiriu o mundio sobre ela; isto porque o marido deve restituir ele mesmo o launegild se lhe for requerido." O referido launegild pode ser compreendido como se fosse sinônimo de "recompensa" ou "contraprestação", como se extrai do capítulo 175, do Edito de Rotário: "175. De launegild. Si quis rem suam cuicumque donaverit et postea, qui donavit, launegild requisiverit, tunc ille, qui accepit, aut heredes eius, si ausus non fuerit iurare, quod conpositum sit, reddat ei ferquido, id est similem, quales in illa diae fuit, quando donatum est; et si iuraverit, sit exsolutus." Tradução livre: "175. Do launegild. Se alguém doa a outrem os próprios bens e depois que doou reclama um launegild, então aquele que o recebeu os bens, ou seus herdeiros, se não ousam jurar que o empenho foi honrado, os restitua ferquido, isto é um valor similar, correspondente àquele do dia em que foi feita a doação; se jura, seja liberado da acusação."

${ }^{23}$ Solidus, às vezes traduzido por "soldo", foi uma moeda criada na época do Imperador Constantino e pesava cerca de $4,55 \mathrm{~g}$ de ouro.
} 
160. Si quis dereliquerit filias legitimas unam aut plures et sorores legitimas unam aut plures et filiûs naturalis unum aut plures, tollant filiae et sorores inter se aequaliter dividendum uncias sex, quod est medietas, naturalis filii uncias quattuor, quod est tertia pars, et duas uncias parentes legitimi, aut curtis regia, si parentes legitimi non fuerint, quod est sexta pars. Pro mundio autem superscriptarum tollant naturales filii tertiam partem et heredes legitimi aut curtis regia partes duas. ${ }^{24}$

Quanto às punições que as mulheres receberiam caso cometessem algum ilícito contra o marido, o Edito de Rotário determinou a pena de morte à acusada de assassinar o marido; contudo, se o marido assassinasse a própria esposa, a solução seria a mera exculpação e a desnecessidade de exercício de violência contra o homem. Nesse caso, pode-se observar a diferença de tratamento entre ambos no disposto no capítulo 166 em relação aos capítulos 202 e 203:

\begin{abstract}
166. De suspitionem in maritum, quod oxorem suam occidissit. Si suspectio fuerit, quod maritus uxorem suam occidisset, ita decernimus, ut purificet se maritus cum sacramentales suos legitimos, quod mixtus in morte ipsius mulieris non fuissit, nec per se, nec per subposita persona, et sit exsolutus ab hoc crimen. Quia absordum et inpossibile videtur esse, ut talis causa sub uno scuto per pugnam dimittatur.
\end{abstract}

202. Si mulier in morte mariti sui consiliaverit per se aut per supposita persona, sit in potestatem mariti de ea facere, quod voluerit; simul et de res ipsius mulieris. Nam si illa negaverit, liceat parentibus eam pureficare aut per sacramentum, aut per camphionem, id est per pugna.

203. Si mulier maritum suum occiderit, ipsa occidatur, et res eius, si filii non fuerint, parentes mariti habeant potestatem. ${ }^{25}$

\footnotetext{
${ }^{24}$ Tradução livre: " 158 . Se alguém deixa uma filha legítima e um ou mais filhos naturais e outros parentes próximos ou herdeiros, divida-se os bens do morto em partes iguais: a filha receba quatro onças, isto é um terço, os filhos naturais quatro onças, isto é um terço, e os parentes próximos ou herdeiros quatro onças, isto é um terço. Se não há parentes próximos, então a corte real receba as suas quatro onças. [...] 159. Se alguém deixa duas ou mais filhas legítimas e um ou mais filhos naturais e outros parentes próximos como supra, as filhas peguem seis onças, isto é a metade, os filhos naturais quatro onças, isto é um terço, e os parentes legítimos duas onças, isto é um sexto. Se não houver parentes, a corte real receba as suas duas onças. [...] 160. Se alguém deixa uma ou mais filhas legítimas e uma ou mais irmãs legítimas e também um ou mais filhos naturais, as filhas e as irmãs recebam seis onças, isto é a metade, para dividirem em iguais partes entre elas, os filhos naturais quatro onças, isto é um terço, e os parentes legítimos, ou a corte real se não houver parentes legítimos, duas onças, isto é um sexto. Além disso, para o mundium das mencionadas, os filhos naturais recebam um terço e os herdeiros legítimos, ou a corte real, dois terços."

${ }^{25}$ Tradução livre: "166. Do marido suspeito de ter assassinado a própria mulher. Se se suspeita que um marido tenha assassinado a própria mulher, estabelecemos que o marido se purifique com os seus juramentadores legítimos, para não ser implicado no assassinato da própria mulher nem diretamente nem por interposta pessoa e seja liberado da acusação. Porque parece absurdo e improvável que uma similar causa seja resolvida sob um escudo, com um duelo. [...] 202. Se uma mulher trama pela morte do próprio marido por si ou interposta pessoa, seja faculdade do marido fazer dela o que desejar; e assim também quanto aos bens da mulher. Mas se ela nega, seja consentido aos seus parentes purificá-la ou com um juramento ou mediante um campeão, isto é, um duelo. [...] 203. Se uma mulher assassina o próprio marido, seja esta mesma morta e seus bens, se não tiveram filhos, sejam de propriedade dos parentes do marido."
} 
Quanto aos ilícitos de cunho sexual praticados por mulheres, geralmente contrários aos interesses patrimoniais dos homens quanto à administração e negociação do mundium, a pena estipulada poderia ser a de morte:

\begin{abstract}
189. De fornicationis causa. Si puella aut mulier liberam voluntariae fornicaverit, cum libero tamen homine, potestatem habeant parentes in eam dare vindictam. Et si forte ambarum partium steterit, ut ille, qui fornicavit, eam tollat uxorem, conponat pro culpa, id est anagrift, solidos viginti; et si non convenerit, ut eam habeat uxorem, conponat solidos centum, medietatem regi et medietatem ad quem mundius de ea pertenuerit. Et si parentes neglexerint aut noluerint in ipsa dare vindictam, tunc liceat gastaldium regis aut sculdhais ipsam ad manum regis tollere et iudicare de ipsa, quod regi placuerit.
\end{abstract}

211. Si quis uxorem alterius tulerit. Si liber aut servus uxorem alterius tulerit eamque sibi in coniugium sociaverit, ambo occidantur, si tamen ambo consenserint.

212. Si quis cum uxorem suam alium fornicantem invenerit. Si quis cum uxorem suam alium fornicantem invenerit, liberum aut servum, potestatem habeat eos ambos occidendi; et si eos occiderit, non requirantur. ${ }^{26}$

Pela análise da norma parece que a conduta mais repudiada em relação às mulheres livres seria a união com pessoas de categoria inferior, sobretudo um servo, visto que o casamento era impossível entre ambos na sociedade longobarda. Do capítulo 193 se extrai: "Si puella libera servum alienum foris provincia secuta fuerit, requirant eos pariter dominus servi et parentes puellae: si eos invenerint, ambo poenam iuxta legem susteneant. Nam culpa ad domino, cuius servus fuerit, non requiratur. ${ }^{27}$ Nesse caso, a lei referida seria o capítulo 221 , que possui a seguinte redação:

221. Si servus liberam mulierem aut puellam ausus fuerit sibi in coniugium sociare, animae suae incurrat periculum, et illa, qui servum fuerit consentiens, habeant parentes potestatem eam occidendi aut foris provincia transvindendi et de res ipsius mulieris faciendi quod voluerint. Et si parentes eius hoc facere

\footnotetext{
${ }^{26}$ Tradução livre: "189. Do caso de fornicação. Se uma jovem ou uma mulher livre fornica voluntariamente, desde que seja com homem livre, os parentes possuem a faculdade de se vingar dela. Se, por acaso, as partes decidirem que aquele que fornicou a tome por esposa, esse pague uma composição pela culpa, isto é, pelo anagrift, de vinte sólidos; se não lhe convier que a faça de esposa, pague uma composição de cem sólidos, metade ao rei e a metade àqueles a que pertence o mundium sobre ela. Se os parentes negligenciarem ou refutarem a vingança contra ela, então seja consentido ao gastaldo ou ao sculdhais colocá-la na mão do rei para ele próprio julgá-la conforme sua conveniência.211. Se alguém pega a mulher de outro. Se um livre ou um servo pegam a mulher de outro e se unem em casamento, sejam ambos assassinados, no caso de ambos terem consentido. [...] 212. Se alguém descobre outro fornicando com sua mulher. Se alguém descobre outro no instante em que fornica com sua mulher, livre ou escravo, tenha a faculdade de assassinar ambos e, se os assassina, não seja requerido.”

${ }^{27}$ Tradução livre: "193. Se uma jovem livre for com um servo para fora da província, persigam-nos, seja o patrão do servo, sejam os parentes da jovem, e se os encontram, submetam-nos a pena segundo a lei, mas não se impute culpa alguma ao patrão do servo."
} 
distulerint, tunc liciat gastaldium regis aut sculdhais ipsam in curte regis ducere et in pisele inter ancillas statuere. ${ }^{28}$

Por outro lado, nas diversas situações jurídicas em que uma mulher aparecesse como ofendida de algum ato ilícito provocado por outrem, fica evidente, no Edito de Rotário, que a injúria seria considerada bastante ofensiva aos detentores do mundium. Deveras, levando em consideração os valores fixados nos capítulos 200 e 201, que tratam de morte de mulher, foi fixada a soma de mil e duzentos solidus ${ }^{29}$, metade aos parentes e metade ao rei, constituindo o maior valor referente à composição previsto em todas as leges Langobardorum.

200. De occisione mulieris. Si maritus uxorem suam occiderit inmerentem, quod per legem non sit merita mori, conponat solidos mille duocentûs, medietatem illis parentibus, qui eam ad maritum dederunt et mundium susciperunt, et medietatem regi, ita ut per actorem regis distringatur, et poena suprascripta conponatur. Et si filius de ipsa muliere habuerit, habeant filii morgingab et faderfio matris suae mortuae. Et si filius ex ipsa non habuerit, revertatur ipsa facultas ad parentes, qui eam ad maritum dederunt. Et si parentes non fuerint, tunc ipsa conpositio et praedicta facultas ad curtem regis perveniat.

201. De muliere libera asto occisa. Si quis puellam aut mulierem liberam per qualibit occasionem occiderit, conponat solidos mille duocentûs, medietatem parentibus, aut ad quem mundius de ipsa pertenit, et medietatem regi. Et si parentes non habuerit, tunc ipsa conpositio in integrum ad curtem regis perveniat; sic tamen, si asto animo, id est volontariae, occiserit. ${ }^{30}$

Novecentos solidus $^{31}$ é o segundo maior valor de composição prevista no Edito, e aparece estipulado nos capítulos 26, 186 e 191. Interessante notar que no caso específico do capítulo 26, a mulher mesma poderia ser destinatária dos valores da composição: "De wegworin, id est horbitariam. Si quis mulieri libere aut puellae in via se anteposuerit aut aliqua iniuria intulerit,

\footnotetext{
28 Tradução livre: "221. Se um servo ousa unir-se em casamento com uma mulher ou jovem livre, sua vida seja colocada em perigo, e no que concerne àquela que deu seu próprio consenso, seus parentes tem a faculdade de assassiná-la ou de vendê-la para fora da província e de fazer aquilo que desejarem com os bens da mulher. Se seus parentes tardarem em fazer isso, então seja consentido ao gastaldo do reino ou outro sculdhais de conduzi-la à corte real e de colocá-la no pisele junto das servas."

${ }^{29}$ Correspondente a aproximadamente $5.460 \mathrm{~g}$ de ouro.

${ }^{30}$ Tradução livre: "200. Do assassinato da mulher. Se um marido assassina a própria mulher inocente, que não tinha o mérito de ser morta pela lei, pague uma composição de mil e duzentos sólidos, metade aos parentes que a deram como esposa e que receberam pelo mundium e metade ao rei, de modo tal que seja constrito por um autor do rei e a supramencionada pena seja composta. Se teve um filho com a mulher, os filhos tenham o morgingab e o faderfio, da sua mãe defunta; se não houver um filho dela, seus bens retornem aos parentes que a deram como esposa. Se não houver parentes, então a composição e os supraditos bens vão à corte real. [...] 201. Da mulher livre assassinada intencionalmente. Se alguém assassina uma jovem ou mulher livre por qualquer motivo, pague uma composição de mil e duzentos sólidos, metade aos parentes, ou àquele que concerne o mundium sobre ela, e metade ao rei. Se não há parentes, então a dita composição vá por inteiro à corte do rei; seja assim, se a assassina intencionalmente, isto é, voluntariamente."

${ }^{31}$ Correspondente a aproximadamente $4.095 \mathrm{~g}$ de ouro.
} 
noningentos solidos conponat, medietatem regi et medietatem cui ipsa iniuria inlata fuerit aut mundius de ea pertenuerit. " 32 (sem grifo no original)

Diversa providência foi prevista no caso de uma mulher ser violentada, pois nesse caso ela não receberia os valores da composição, mas continuariam sendo controlados seus interesses, $a$ priori, pelos detentores de seu mundium:

186. De violentia. Si vir mulieri violentias fecerit, et invitam tullerit uxorem, sit culpabilis sold. nongentos, medietatem regi et medietatem parentibus mulieris: et si parentes non habuerit, ipsi nongenti solidi ad curtem regis exegantur. Et mulier ipsa licentiam habeat cum omnes res suas proprias, quae ei lege perteneunt, elegendum, qui mundium eius in potestatem debeat habere, vult ad patrem, si habuerit, vult ad fratrem, vult ad barbanem, vult ad manum regia: in ipsius mulieris sit potestatem, ubi sibi ipsa elegerit. ${ }^{33}$

As regulamentações que mais ilustram uma tutela aos interesses das mulheres longobardas aparecem nos capítulos 195 a 198, em que, em termos gerais, os detentores do mundium que se tornassem ofensores poderiam ser apenados com a destituição de tal poder:

195. De crimen in puellam iniecto. Si quis mundium de puella libera aut muliere poteltatem habens, excepto pater aut frater, et in animam ipsius puellae aut mulieris insidiatus fuerit aut alii invitam ad maritum tradere voluerit, aut volentibus ad eius violentiam faciendam consensum praebuerit aut consilium dederit, ut provatur, ammittat mundium ipsius, et illa potestatem habeat de duas vias: vult ad parentis reverti vult ad curtem regis cum rebus suis propriis, quae ad eam per legem pertenent, se commendare, qui mundium eius in potestatem debeat habere. Et si vir ille ista crimina negaverit, liceat eum se pureficare et mundium, sicut habuit habere, si se pureficaverit.

196. De crimen adulterii. Si quis mundium de puella libera aut muliere habens, excepto patre aut fratre, et crimen ei iniecerit, quod adulterassit, amittat mundium ipsius, et illa potestatem habeat cum rebus suis propriis vult ad parentis reverti, vult ad curtem regis se commendare, qui mundium eius in potestatem debeat habere. Et si vir ille hoc crimen dixissit negaverit, liceat eum se pureficare, si potuerit, et mundium eius, sicut habuit, habere.

197. De crimen nefandum. Si quis mundium de puella libera aut muliere habens eamque strigam, quod est mascam, clamaverit, excepto pater aut frater, ammittat mundium ipsius, ut supra, et illa potestatem habeat vult ad parentes, vult curtem regis cum rebus suis propriis se commendare, qui mundium eius in potestatem debeat habere. Et si vir ille negaverit, hoc crimen non dixissit, liceat eum se pureficare et mundium, sicut habuit, habere, si se pureficaverit.

\footnotetext{
32 Tradução livre: "201. Da mulher livre assassinada intencionalmente. Se alguém assassina uma jovem ou mulher livre por qualquer motivo, pague uma composição de mil e duzentos sólidos, metade aos parentes, ou àquele que concerne o mundium sobre ela, e metade ao rei. Se não há parentes, então a dita composição vá por inteiro à corte do rei; seja assim, se a assassina intencionalmente, isto é, voluntariamente."

${ }^{33}$ Tradução livre: "186. Da violência. Se um homem violentar uma mulher e a tomar como mulher contra sua vontade, seja condenado a pagar novecentos sólidos, metade ao rei e metade aos parentes da mulher; se não há parentes, os novecentos sólidos sejam recolhidos à corte real. A mulher tenha, junto com todos os seus bens pessoais, que lhe concernem por lei, licença para escolher quem deva ter o poder de seu mundium, quer o pai, se o tiver, quer o irmão, quer o barba, quer a mão do rei: seja faculdade da mulher, como ela mesma escolhe por si."
} 
198. De crimen in puella iniectum, qui in alterius mundium est. Si quis puellam aut mulierem liberam, qui in alterius mundium est fornecariam aut histrigam clamaverit etpulsatus penitens manefestaverit, per furorem dixissit, tunc praeveat sacramentum cum duodecim sacramentalis suos, quod per furorem ipso nefando crimen dixissit, nam non de certa causa cognovissit. Tunc pro ipso vanum inproperii sermonem, quod non convenerat loqui, conponat solidos vigenti, et amplius non calumnietur. Nam si perseveraverit et dixerit, se posse probare, tunc per camphionem causa ipsa, id est per pugnam, ad dei iudicium decernatur. Et si provatum fuerit, illa sit culpabilis, sicut in hoc edictum legitur. Et si ille, qui crimen misit, provare non potuerit wergild ipsius mulieris secundum nationem suam conponere conpellatur. ${ }^{34}$

Enfim, como foi possível observar, as normas do Edito de Rotário não parecem refletir uma pretensa proteção aos interesses das mulheres. Do mesmo modo, não emergem ao longo do texto referências a questões místicas que as envolvam. Fica evidenciado, ao revés, que os homens tinham poderes em relação à administração de seus bens e, nos casos em que elas mostrassem algum tipo de renitência aos negócios estabelecidos pelos detentores do mundium, poderiam sofrer duras punições ou, quando eram ofendidas, seus parentes é que seriam os beneficiários dos valores correspondentes às composições estabelecidas pela lei.

\section{As mulheres nas Leis de Grimoaldo}

No reinado do rei Grimoaldo (662-671) foram acrescidos, no ano de 668, nove capítulos ao Edito de Rotário, compondo o complexo denominado Leges Langobardorum. Para comprovar sua

\footnotetext{
34 Tradução livre: "195. Das acusações por condutas cometidas contra uma jovem. Se alguém, tendo o poder de mundium sobre uma jovem ou uma mulher livre, a menos que seja pai ou irmão, atenta contra a vida daquela jovem ou mulher, ou deseja dar-lhe um marido contra sua vontade, ou dá o seu consenso a quem deseje violentá-la, ou dá a ele uma sugestão, e isto é provado, perca o seu mundium e ela tenha a faculdade de duas vias: ou retornar para os parentes ou se entregar, com os bens de sua propriedade conferidos pela lei, para a corte real, que deverá ter em poder o seu mundium. Se o homem nega ter pronunciado tal acusação, seja-lhe permitido escusar-se e, se se escusa, possua o seu mundium assim como o possuía. [...] 196. Da acusação de adultério. Se alguém, tendo o mundium sobre uma jovem ou uma mulher livre, a menos que seja seu pai ou irmão, move contra ela a acusação de ser adúltera, perca o seu mundim e ela possua a liberdade, com os bens de sua propriedade, ou de retornar aos seus parentes ou de se entregar à corte real, que terá o poder de seu mundium. Se o homem negar ter pronunciado tal acusação, seja-lhe consentido escusar-se, se puder, e possuir o seu mundium assim como o possuía. [...] 197. Da acusação abominável. Se alguém, possuindo o mundium sobre uma jovem ou uma mulher livre, a chama de bruxa, isto é, feiticeira, a menos que seja o pai ou irmão, perca o seu mundium, como supra, e ela tenha a faculdade ou de retornar aos parentes ou de se entregar, com os bens de sua propriedade, à corte real, que terá de ter em seu poder seu mundium. Se o homem nega ter pronunciado tal acusação, seja-lhe permitido escusar-se e possuir o seu mundio assim como o possuía, se se escusa. [...] 198. Da acusação movida contra uma jovem que está sob o mundium de outrem. Se alguém chama de prostituta ou bruxa uma jovem ou uma mulher livre que está sob o mundium de outrem e, acusado, se declara arrependido e afirma tê-lo dito movido pela ira, então preste o juramento com seus doze juramentadores de ter dito aquela nefanda acusação movido pela ira, sem ter compreensão certa. Então por estas vãs palavras injuriosas, que não deveria pronunciar, pague uma composição de vinte sólidos e não venha mais a ser acusado. Mas se insiste e diz poder prová-lo, então a causa seja resolvida por um campeão, isto é, um duelo, segundo o Juízo de Deus. E se vier a ser provada, aquela seja passível de pena conforme se lê neste Edito; mas se aquele que moveu a acusação não puder prová-la, seja compelido a pagar o wergild segundo o nascimento da mulher."
} 
legitimidade como legislador, Grimoaldo fez expressa referência, no prólogo, ao disposto no capítulo 386 do Edito de Rotário: "Superiore pagina huius edicti legitur ita, quod adhuc annuente domino memorare potuerimus de sincolas causas, quae in presente non sunt adficte, in hoc edictum adiungere debeamus ita, [...]", 35

Também no prólogo pode-se verificar que as normas jurídicas acrescidas por Grimoaldo teve "[...] persuggestione iudicum omniumque consensu ea, $[\ldots]$ "..36 sugerindo de que a atividade legislativa no Reino Longobardo continuaria sendo uma confirmação do direito consuetudinário, que estaria em constante mutação e adaptações e, ainda, que os dispositivos acrescidos ao Edito seriam orientações para o exercício da jurisdição naquelas causas em que as normas anteriores fossem omissas ou que precisavam ser modificadas.

Em relação às mulheres, foram acrescentadas 3 novas normas:

6. De uxoribus dimittendis. Si quis uxorem suam absque culpam legitimam posposuerit, et alia in domo superinduxerit, conponat solidos quingentos, medietatem regi et medietatem parentibus mulieris; mundio vero eius mulieris, quam postposuit, amittat; et si noluerit ad maritum suum reverti, revertatur ad parentes suos cum rebus suis et mundium.

7. De crimen uxoris. Si quis uxorem suam incriminaverit asto sine causa legitima, quasi adulterassit aut in animam mariti sui tractassit, liceat illi mulieri per sacramentum parentum aut per pugnam se mundare. Et si purificata fuerit, tunc maritus eius praebeat sacramentum cum parentibus suis legitimis, sibi duodecimus, quia non asto animo nec dolose ei crimen iniecit, ut eam deberet dimittere, nisi per certam suspectionem auditum habuisset haec verba; et si haec fecerit, sit exolutus a culpa. Et si non fuerit ausus iurare, conponat virgild ipsius mulieris, tamquam si fratrem eius occidisset, medietatem regi et medietatem perentibus mulieris.

8. Si mulier aut puella notum habuerit quemcumque habere uxorem, et super ipsam introierit et tulerit ei maritum non suum: iubemus ut omnes res suas perdat ipsa mulier, qui sciendo alterius marito volontariae consensit; et medietatem de rebus eius accipiat curtis regia et medietatem parentibus. Et illam priorem mulierem recipiat maritus suus, et colat eam, ut decet uxorem legitimam. Vitium suum reputet, quae super alienam uxorem introire presumpsit, et nihil ei conponatur, et faida non requiratur. ${ }^{37}$

\footnotetext{
${ }^{35}$ Tradução livre: "Em uma página precedente deste Edito se lê assim, que devemos acrescentar a este Edito o que até aqui está em grau de recordar, com o favor de Deus; [...]"

${ }^{36}$ Tradução livre: "[...] o conselho dos juízes e o consenso de todos, [...]"

${ }^{37} 6$. Das mulheres repudiadas. Se alguém abandona a própria mulher sem um legítimo motivo e a manda para uma casa alheia, pague uma composição de quinhentos sólidos, metade ao rei e metade aos parentes da mulher; perca também o mundium sobre a mulher que abandonou. Se aquela não deseja retornar ao seu marido, retorne aos seus parentes, com os seus bens e com seu mundium. [...] 7. Da acusação à mulher. Se alguém incrimina a própria mulher sem causa legítima, como se tivesse cometido adultério ou tramado contra a vida de seu marido, seja consentido à mulher escusar-se mediante juramento dos parentes ou duelo. Se for purificada, então seu marido preste juramento com seus parentes legítimos, fazendo-se ele mesmo como o décimo segundo, de não ter movido a incriminação intencionalmente nem com o escopo de dolo para poder deixá-la, mas de ter ouvido tais palavras como uma suspeita fundada. Se não ousa jurar, pague o virgild da própria mulher. Como se tivesse matado o irmão dela, metade ao rei e metade aos parentes da mulher. [...] 8. Se uma mulher, ou uma jovem, vier a saber que um
} 
Como é possível notar, o capítulo 06 regulamentou a composição e a situação do mundium das mulheres que tivessem sido indevidamente rejeitadas pelos maridos, mostrando que o rei mantinha o interesse na tutela "pública" dos assuntos envolvendo mulheres do reino.

No capítulo 07 foi tratado dos casos de falsa acusação à própria mulher, por adultério ou trama na morte do marido. Nesse caso, Grimoaldo permitiu a exculpação da mulher por intermédio de juramento de seus parentes ou duelo, se assemelhando, portanto, aos capítulos 196 e 202 do Edito. A diferença, porém, estava na hipótese de que a esposa fosse devidamente purificada e, portanto, demonstrada a impropriedade da acusação formulada pelo marido, este teria que se desculpar mediante juramento, devendo declarar que não moveu a acusação de má-fé. No caso em que o marido não fizesse o juramento, este então deveria pagar, à própria mulher, a quantia correspondente ao virgild ${ }^{38}$ de um irmão dela.

Quanto ao capítulo 08, há um discurso jurídico bastante peculiar, porquanto regulou as situações em que mulheres tentariam se unir a homens já casados e, por presunção de darem o seu consenso, deveriam perder todos os bens, em favor da coroa régia e dos próprios parentes. Isso acrescido da recomendação de que a esposa legítima deveria cuidar do marido e, outrossim, foi determinada a proibição do homem que pegasse uma mulher de maneira irregular de procurar composição ou exercer a faida ${ }^{39}$ Como se observa, Grimoaldo quis dizer que o homem que se unisse a uma mulher diversa da sua não tinha razão e, então, o privou de declarar-se ofendido e procurar exercitar o seu pretenso ius puniendi; mas a mulher seria punida com a perda de todos os bens.

\section{As mulheres nas Leis de Liutprando}

O rei Liutprando foi um dos personagens mais importantes da política alto- medieval do século VIII e promoveu, ao longo de seu reinado (712-744), quinze alterações legislativas através

\footnotetext{
tem mulher e se avança sobre ela e leva embora um marido não seu, ordenamos que a mulher que deu o próprio consenso voluntário a um marido, sabendo ser alheio, perca todos os seus bens; metade dos seus bens receba a corte do rei e metade os parentes. Aquela primeira mulher pegue o seu marido e cuide dele como se faz uma mulher legítima. Aquele que ousou ir adiante, pegando uma mulher alheia, considere presunção própria e não lhe seja paga qualquer composição e não procure a faida.

${ }^{38}$ Segundo Heirich Brunner, (1936, p. 12) wergeld ou manngeld significa, "literalmente: compositio homicidii, preço ou dinheiro (geld) do homem (wer = mann, vir)". No mesmo sentido (CARBASSE, 2000, p. 91): "le wergeld (= le prix de l'homme."). Nas Leges Langobardorum, o mesmo instituto jurídico germânico aparece redigido com nomes diversos, como wergild (Edito de Rotário, capítulos 09, 11, 198 e 268); virgild (Leis de Grimoaldo, no comentado capítulo 7); wirgild (Leis de Liutprando, capítulos 30, 35, 83, 85, 91, 119); wirigild (Leis de Liutprando, capítulos 48, 63, 100,121,122, 130, 135, 143 e 144; Leis de Ratchis, capítulos 7, 10, 11); widrigild (Aviso aos autores do rei, capítulo 2; Leis de Ratchis, capítulos 01, 03 e 04; Leis de Astolfo, capítulos 04, 06, 08); widricild (Leis de Ratchis, capítulo 13).

${ }^{39}$ Inimizade, revide, guerra privada.
} 
de blocos anuais, em um total de 153 novos capítulos, acrescentando, modificando ou suprimindo disposições normativas do Edito de Rotário e das Leis de Grimoaldo. ${ }^{40}$ De maneira ampla, é possível observar que, sobretudo a partir do ano de 720, os capítulos foram sendo carregados de justificativas para a determinação das novas regras, dando caráter de "jurisprudência" oficial, que iriam sendo registradas para orientação jurídica aos juízes e demais autoridades judicantes longobardas.

Dos capítulos acrescentados no decorrer do reinado de Liutprando que regulamentam situações envolvendo mulheres, treze deles trataram das regulamentações jurídicas patrimoniais; sete estipularam ou ratificaram punições; treze mencionaram uma suposta proteção a elas e quatro trataram de regras para aquelas que optaram por seguir a vida religiosa.

Sua primeira manifestação legislativa foi no ano de 713 e, dos seis capítulos acrescidos, todos tratam de direito sucessório. Realizaram, deste modo, importantes modificações de cunho patrimonial a favor de filhas legítimas solteiras, que passaram a herdar a totalidade dos bens na ausência de filho herdeiro masculino: "1. Si quis langobardus sine filiis masculinis legetimis mortuos fuerit, et filias dereliquerit, ipsae ei in omnem hereditatem patris vel matris suae, tamquam filii legetimi mascolini, heredis succedant." "41

Foram também realizadas modificações entre os capítulos 158 e 160 do Edito de Rotário, em que Liutprando procurou equiparar as filhas mulheres aos filhos homens, permitindo que, em diversas situações familiares, elas passassem a herdar. Não obstante, o poder privado dos homens continuou sobre as mulheres, como registrado no capítulo 5: "Si filiae aut sorores contra volontatem patris aut fratris egerit, potestatem habeat pater aut frater iudicandi de rebus suis, quomodo aut qualiter voluerit." 42

Nas normas editadas no ano de 717, Liutprando, já no proêmio das novas normas, declarou: "Primum omnium de morgingab mulierum." ${ }^{43}$ Com efeito, no capítulo 7 obrigou que os bens doados pelo marido na condição de morgingab deveriam ser declarados perante parentes e amigos, limitando o valor a ser doado em até um quarto de seu patrimônio, e não mais. No capítulo 12, por sua vez, foi estabelecida a proibição de casamento com criança:

\footnotetext{
${ }^{40}$ No ano de 713 foram acrescidos seis capítulos; oito capítulos em 717; quatro capítulos em 720; onze capítulos em 721; vinte e quatro capítulos em 723; onze capítulos em 724; cinco capítulos em 725; catorze capítulos em 726; doze capítulos em 727; oito capítulos em 728; treze capítulos em 729; treze capítulos em 731; nove capítulos em 733; quatro capítulos em 734; onze capítulos em 735.

${ }^{41}$ Tradução livre: "1. Se um longobardo morre sem filhos legítimos masculinos, mas deixa filhas, estas o sucedam como herdeiras de toda a herança do pai ou da mãe, como se fossem filhos masculinos legítimos."

${ }^{42}$ Tradução livre: "Se as filhas ou irmãs agirem contra a vontade do pai ou do irmão, o pai ou o irmão tenha a faculdade de decidir sobre seus bens do modo e na medida que quiser."

${ }^{43}$ Tradução livre: "Antes de tudo, a respeito do morgingab das mulheres."
} 
12. De puella quae intra etatem est. Si quis puella ante duodecim annos spunsaverit aut tolerit, tunc ille qui eam tolit aut spunsavit, conponat, sicut edictum de raptum contenit: hoc est solidi nongenti, medietatem regi et medietatem eidem infantole, et ipsa revertatur in casa et in pecuniam suam et sit quieta usque ad suprascriptum tempus; postea autem elegat ipsa sibi, et nubat, cui voluerit. Si autem mundoald eius consentiens fuerit, aut tradederit eam ante suprascriptos duodicem annos, conponat in sagro palatio solidos trecentos, et mundium eius amittat, et sit ipsa cum rebus suis in mundio palatii. Pater autem aut frater potestatem habeant, cui aut in quali etate voluerit, dandum aut spunsandum filiam aut sororem suam; quoniam ista licentia ideo dedimus, eo quod credimus, quod pater filiam aut frater sororem suam doloso animo aut contra rationem cuiquam homini dare non debeant. ${ }^{44}$

No ano de 721 houve a regulamentação, no capítulo 22, sobre o procedimento de venda de bens da mulher com o consenso do marido. Através deste surge a obrigação dela de declarar perante os parentes que não estaria sendo vítima de violência para dispô-los. Em caso contrário, se reclamasse ter sido compelida, a venda passava então a ser considerada inválida. Entre as normativas emanadas em 721, é significativa a mudança na penalidade estabelecida nos capítulos 193, 211, 212 e 221 do Edito de Rotário no que tange à providência a ser adotada no caso de uma mulher livre se relacionar com um servo. Nesta, estabelecido um período prescricional de um ano para que os parentes exercessem a vingança sobre ela:

24. Si mulier libera servum tolerit, et parentes eius intra anni spatium in ea vindicta dare neglexerit, sicut in anteriore edicto contenit, tunc quandocumque post ipsum anni spatium inventa fuerit, sit ancilla palatii; et ipse servus ad puplicum replecetur, et filii, qui ex eis nati fuerent, curtis regiae omnino deserviant. Nam si parentis ipsius mulieris, vel dominus servi conpleverent intra suprascriptum anni spatium quod anterior edictus contenit, sic permaneat. ${ }^{45}$

No décimo-primeiro ano do reinado de Liutprando, em 723, foram emanadas normas a respeito da situação patrimonial das mulheres em diversas situações, com especial ênfase a assuntos

\footnotetext{
44 12. Da jovem que é menor de idade. Se alguém contrai os esponsais ou pega uma jovem abaixo dos doze anos, então aquele que a pegou como mulher, ou que contratou os esponsais com ela, pague uma composição como prevê o Edito por rapto, isto é, novecentos sólidos, metade ao rei e metade à infante, e ela retorne à sua casa com seu pecúlio e permaneça imperturbada até o tempo supra escrito; após, escolha por si e se case com quem queira. Se depois o seu mundoald deu seu próprio consenso e a consignar antes dos ditos doze anos, pague ao sacro palácio uma composição de trezentos sólidos e perca o seu mundium e aquela esteja com seus bens sob o mundium do palácio. Porém o pai, ou o irmão, possuem a faculdade de dar ou fazer contrair os esponsais à própria filha, ou irmã, com quem desejam, na idade que quiserem; concedemos esta faculdade porque acreditamos que um pai não dará jamais a própria filha, ou um irmão a própria irmã, com intenções dolosas e contra a norma.

45 24. Se uma mulher livre se relaciona com um servo e seus parentes negligenciam de exercitar a vingança sobre ela dentre um ano, como está prescrito no Edito anterior, então, em qualquer momento que venha a ser encontrada depois daquele período de um ano, seja serva do palácio. O servo seja entregue ao público e os filhos que são nascidos deles sirvam todos à corte régia. Se, em vez disso, os parentes da mulher, ou o patrão do servo, cumprem entre o predito período de um ano aquilo que prescreve o Edito anterior, permaneça assim.
} 
pertinentes à moral cristã, como é possível observar nos capítulo 30 a 34, surgindo, cada vez com mais expressão, a tutela do rei no disciplinamento cristão das famílias no reino longobardo.

No capítulo 30 foi fixada a jurisdição do rei para decidir sobre as condições materiais (vestes e alimentos) das mulheres que abandonariam o hábito religioso para se casar:

\begin{abstract}
30. De his feminis, quae velamen sancte religionis suscipiunt, aut quae a parentibus suis deo vovintur, aut ipsae se elegunt, religionis habitu aut vestem monastiga induere vedentur, quamquam a sacerdote consegrate non sint, sic nobis iustum paruit esse pro dei amore, ut in ipso habitu in omnibus perseverent, nec sit excusatio mali hominibus dicendo: "Quod sacrate non sunt, ideo, si copolantur, culpa non habent". Sed, ut supra premisemus: quae talem signum super se, id est velamen et veste sancte dei genetrices mariae, quocumque genio in se suscipiunt, et postea ad saecularem vitam vel habitu transire nullatinus presumat. Quia considerare devit omnes cristianus, quod si quiscumque saeculares parentem nostram saecularem disponsat, cum solo anolo eam subarrat et suam facit, et si postea alter eam oxorem ducit, culpaviles invenitur solidos sexcentos: quantu magis devit causa dei et sanctae mariae amplior esse, ut, quae ipsum velamen vel habitu in se suscipiunt, in eodem deveant perseverare. Si qua vero femina contra hoc, quod nostra instituit excellentia, egerit aut maritum se copolaverit, perdat omnem substantiam suam, et deveniat ipsa substantia ad potestatem palatii; de persona autem eiusdem femine, quae talem malum comiserit, iudecit rex, qui pro tempore fuerit, qualiter illi placuerit: aut in monasterio mittendo, aut qualiter secundum deum melius previderit. Simili modo et de victu vel vestimentu eius ipse princeps ordinet, qualiter ei placuerit. Si autem ille, in cuius mundio talis femina est, consentiens fuerit in suprascripto malo, et provatum fuerit, conponat wirgild suum; et ille, qui eam tollere presumpserit, conponat in palatio solidos sexcentos. Si autem mundoald in ipso malo consentiens non fuerit, medietatem de ipsis sexcentis solidis accipiat ipse, et medietatem rex. Qui autem talem feminam rapuerit, conponat solidos mille, ut precedat causa dei solidis centum, quoniam de raptu secularis feminae conpositio nongenti solidi in edicto lecuntur. Ipsa vero, quae non conservaverit ea, quae superius legitur, et malo suprascripto consenserit, poenae suprascriptae subiaceat. ${ }^{46}$
\end{abstract}

\footnotetext{
${ }^{46}$ Tradução livre: " 30 . A respeito das mulheres que adotam o véu da santa religião ou são devotadas a Deus pelos seus parentes ou que escolhem por si adotar o hábito religioso ou a veste monástica, embora não estejam consagradas por um sacerdote, a nós parece justo pelo amor de Deus que permaneçam, em tudo, com aquele hábito e não haja justificação por aqueles homens malvados que dizem: 'Do momento em que não são consagradas, não possuem culpa se copularem.' Mas, como já dissemos supra: aquelas que pegarem o signo sobre si, isto é, o véu ou a santa veste de Maria mãe de Deus, por qualquer motivo, depois não ouse de nenhum modo retornar para vida ou hábito secular. Porque todos os cristãos devem considerar que se um qualquer, que vive no século, contrai os esponsais com uma nossa similar no século, empenha-a e a faz sua com um anel e se depois outro a pega por mulher, este último é condenado a pagar seiscentos sólidos; quanto maior deve ser a causa de Deus e da Santa Maria, tanto que quem pega sobre si o véu ou o hábito deve perseverar nisso. Se uma mulher age contra estas coisas que estão instituídas pela nossa excelência e se conjuga com um marido, perca todo o seu patrimônio e tal patrimônio venha em poder do palácio; a respeito da pessoa daquela mulher que cometeu tal má ação, julgue o rei daquele tempo, como desejar. Do mesmo modo, o príncipe disponha como lhe desejar também a respeito do seu alimento e de suas vestes. Por outro lado, aquele em cujo mundium se encontrava a mulher, deu o seu consenso para a supramencionada má-ação e se isto vier a ser provado, pague como composição o seu wirgild; e aquele que ousou pegá-la, pague uma composição de seiscentos sólidos ao palácio. Se, ao contrário, o seu mundoald não deu o seu consenso para aquela má-ação, receba ele mesmo metade daqueles seiscentos sólidos e metade ao rei. Quem rapta uma tal mulher, pague uma composição de mil sólidos, de modo que a causa de Deus seja superior a cem, do momento que no Edito se lê que a composição pelo rapto de uma mulher do século é de novecentos sólidos. Aquele que não observa estas coisas que se leem acima e dá o seu consenso para a supramencionada má-ação submeta-se à pena supra escrita."
} 
Em sua obra "Medioevo del Diritto", o historiador italiano Francesco Calasso (1954, p. 222) salienta que a norma disposta no interior do capítulo 30 testemunha a difículdade dos longobardos em aceitar os princípios da sacralidade cristã envolvendo a situação jurídica tradicional de mulheres negociadas para o casamento entre os detentores de seu mundium. A razão de tal dificuldade adviria do fato da cultura germânica antiga contemplar o casamento como consumado com a traditio (entrega) da mulher, tida como objeto de negociação entre homens livres. A colisão se dava, justamente, em razão de a doutrina católica afirmar que a mulher religiosa "figurava come soggetto e stava, con personalità giuridica autonoma, di fronte all'uomo." (Ibidem) Liutprando, nessa perspectiva, estaria impedindo que as mulheres já transformadas em religiosas se tornassem objeto de contratos de núpcias entre seus súditos.

No capítulo 31 Liutprando pareceu tentar ajustar a tutela às mulheres vítimas de rapto, pois parte da composição prevista nos capítulos 197, 198 e 191, do Edito de Rotário, que deveria ser entregue aos parentes da mulher, passaram a pertencer a elas. Assim, o rei passaria a receber metade da composição e a mulher a outra metade; excetuada a nova regra se os representantes do mundium continuassem sendo o pai ou irmão da ofendida:

31. Si quis rapuerit qualecumque femina libera saecularem, unde in anteriore edicto legitur conpositio solidorum nongentorum, ita volumus, ut de illis quadrigentis quinquagenta solidis, qui perteneunt ad parentes vel ad mundoald, ut accipiat ex ipsis solidis mundoald, qui fuerit, pro fatigio suo ex acceptione de ipsa poena solidos numero centum quinquaginta. Reliquos vero trecentos habeat ipsa femina, cui tales iniuria aut detractio facta est. Si autem patrem aut fratrem ipsa femina habuerit et in eorum mundium fuerit, tunc pater aut frater de ipsam conpositionem, quod sunt solidi quadringenti quiquaginta, faciant cum filia aut sorore sua qualiter voluerint. Nam alter mundoald aut parentes sic dividant ipsam conpositionem, sicut supra statuimus. ${ }^{47}$

O capítulo 32 fez expressa referência à regulação normativa eclesiástica - os cânones - em relação a filhos nascidos de uma considerada união ilícita:

32. De his, qui de inlicito matrimonio nati sunt, vel nascuntur, id est de matrinia, filiastra vel cognata, quod est uxor fratris aut soror uxoris, quia et canones si habent de duabus sororibus, sicut et de duobus fratribus: qui de tale matrimonio

\footnotetext{
47 31. Se alguém rapta uma mulher secular livre qualquer, cujo Edito precedente prevê uma composição de novecentos sólidos, queremos assim, que daqueles quatrocentos e cinquenta sólidos que correspondem aos parentes ou mundoald, aquele que naquele momento é mundoald, daqueles sólidos receba cento e cinquenta, pelo seu incômodo para o resgate da pena. Os restantes trezentos os tenha a mulher mesma a quem foi feito tal degradante ultraje. Se, porém, a mulher tem um pai ou irmão, e está sob o mundium deles, então o pai, ou o irmão, façam o que quiserem com a própria filha, ou irmã, a respeito daquela composição que é de quatrocentos e cinquenta sólidos. Outro mundoald, ou os parentes, dividam entre eles a composição, como estabelecemos supra.
} 
natus fuerit, heredes legitimus patri suo non sit, nisi habeant ipsas res parentes propinqui; et si parentes non fuerint, succedat curtis regia. ${ }^{48}$

No capítulo 33 há declarada influência da influência da Igreja Católica na modificação dos institutos de direito de família entre os longobardos, proibindo casamento de homens com viúvas de sobrinhos ou dos filhos de sobrinhos, cuja sanção seria a perda do patrimônio e a proibição dos filhos havidos da união "ilícita" herdarem. Do ponto de vista político, porém, o capítulo 33 fornece uma informação histórica importante: "Hoc autem ideo adfiximus, quia deo teste papa urbis romae, qui in omni mundo caput ecclesiarum dei et sacerdotum est, per suam epistolam nos adortavit, ut tale coniugium fieri nullatinus permitteremus." 49

Tal menção formal do rei longobardo, reconhecendo o Papa como chefe da Igreja "in omni mundo", permite vislumbrar que o rei reconhecia estar fulcrado na autoridade papal para promover a alteração normativa em relação aos matrimônios, isso porque o rei não teria poderes suficientes para alterar os costumes de seus súditos, mas seu papel primordial na tradição germânica seria reconhecê-los e garantir a sua observância. Ainda, ao declarar que os sacerdotes estavam sob a chefia da Igreja, Liutprando admitiu que a jurisdição eclesiástica - que era a romana - seria autônoma em relação ao próprio poder régio dos longobardos e, por isso, um forte indício do vigor do princípio da territorialidade das leis longobardas entre os súditos do reino e a coexistência do direito romano entre os religiosos.

A influência dos sacramentos cristãos na legislação longobarda do século VIII também fica bastante evidente no capítulo 34, cuja sanção é a mesma do capítulo 33:

34. Item hoc censemus adque precipimus, ut nullus presumat cummatrem suam uxorem ducere, sed nec filiam, quam de sacro fonte levavit; neque filius eius presumat filiam illius uxorem ducere, qui eum de fonte suscepit, quia spiritualis germani esse noscuntur. Et qui hoc malum facere temptaverit, perdat omnem substantiam suam, et filii, qui de inlicito matrimonio nascuntur, heredes esse non debeant, nisi parentes propinqui; et si parentes propinqui non fuerint, curtis regia succedat. Ubi autem inventi fuerint, qui suprascripta inlicita coniugia contraxerint, de presenti separentur, et poenae suprascriptae subiaceant. ${ }^{50}$

\footnotetext{
48 32. Daqueles que nasceram ou nascerão de um matrimônio ilícito, isto é, de uma madrasta, de uma enteada, ou de uma cunhada, que é mulher de um irmão ou a irmã da mulher, porque também os Cânones estabeleceram acima a propósito de duas irmãs, assim como também dos dois irmãos; quem nasce de um tal matrimônio não seja herdeiro legítimo de seu pai; mas tenham antes aqueles bens os parentes próximos. Se não houver parentes próximos, suceda a corte régia.

49 Tradução livre: “Acrescentamos isto porque, Deus é testemunha, o Papa da cidade de Roma, que é em todo o mundo o chefe da Igreja de Deus e dos sacerdotes, nos exortou com uma carta a não permitir absolutamente que aconteçam tais uniões."

${ }^{50}$ Tradução livre: "34. Decretamos e estabelecemos também isto, que ninguém ouse pegar como mulher a sua madrinha e nem a filha que levou à sacra fonte; e nem seu filho ouse pegar como mulher a filha daquele que o recebeu na fonte, porque se os reconhece serem irmãos espirituais. Quem tenta cometer esta má-ação perca todo o seu patrimônio e os filhos que nasceram de um matrimônio ilícito não devem ser herdeiros, mas sejam os parentes
} 
No ano seguinte, em 724, Liutprando editou somente uma norma com referência direta à conduta de mulher: "60. Si aldius cuiuscumque cum libera muliere aut puella fornigatus fuerit, conponat solidos quinquaginta ei, in cuius mundium ipsa fuerit, et illa repotit vitium suum, pro eo quod aldioni consensit. " 51 Em relação à essa, no silêncio da lei, continuaria sendo aplicado o capítulo 189, do Edito de Rotário, exigindo a vingança dos parentes contra a mesma, com possibilidade de bani-la do Reino ou, no caso de negligência dos parentes, a submissão ao julgamento perante o rei.

Sem muitas considerações quanto às normas do ano de 725 em relação às mulheres, no ano de 726 foram descritas várias situações em que ora elas poderiam ser objeto de tutela direta e ora como personagem de alguma conduta ilícita. Nesse caso, parte do capítulo 72 estipulou punição de pagamento de cem solidus ao homem livre que induzisse outro homem livre a incendiar casa de outro ou de pegar ou raptar mulher de outrem.

No capítulo 76 foi tratada a situação de mulheres religiosas que mantivessem relações com um homem. Equiparadas às mulheres casadas, teriam cometido, portanto, o ilícito comparado ao “adultério", expressamente mencionado o Edito de Rotário (capítulo 189). A obrigação do homem com a qual tivesse se envolvido seria a de pagar em dobro a composição, devido à importância da causa envolvendo a religião. Quanto à mulher, seria aplicado o capítulo 30, das próprias Leis de Liutprando:

76. De religiosa femina, quae vestem et habitum sancte religionis in se suscepit, si contegerit ex peccato, ut adulterium volontariae comittat, qui ipsa sanctemonialem feminam adulteraverit, conponat solidos CC; quia de secularibus feminis edictus conte netur, ut conponatur pro adulterium sol. $C$, et nos prospeximus veram esse iustitiam, ut in dei omnipotentis causam et sancte eius genetricis mariae, cuius vestem suscipiunt, duplicentur. De pecunia autem eiusdem religiosae feminae, quae, quod absit, volontariae adulterium penetraverit, sic fiat, sicut iam antea de religiosis feminis statuimus, quae se marito copolaverit. ${ }^{52}$

próximos. Se não houver parentes próximos, suceda a corte régia. Quando forem encontrados [aqueles] que contrataram as supraditas uniões ilícitas, sejam imediatamente separados e submetam-se à pena supra escrita."

${ }^{51}$ Tradução livre: "60. Se o aldius de alguém fornica com uma mulher ou com uma jovem livre, pague uma composição de cinquenta sólidos àquele a que ela está sob o mundium, e aquela considere culpa própria, porque deu o seu consentimento para um aldius."

${ }^{52}$ Tradução livre: "76. Em relação à mulher religiosa, que veste e assume a condição da santa religião, se o pecado a leva a cometer voluntariamente adultério, aquele que cometeu adultério com aquela mulher consagrada a Deus pague uma composição de duzentos sólidos; do momento que o Edito prevê pelas mulheres do século que, pelo adultério, paguem-se cem sólidos, nós consideramos que seja verdadeira justiça se duplique na causa de Deus onipotente e da Sua santa mãe Maria, da qual pegou a veste. A respeito do dinheiro daquela mulher religiosa que, não é mais, que cometeu adultério voluntariamente, seja assim como já estabelecemos precedentemente pelas mulheres religiosas que se unem a um marido." 
No ano de 727, Liutprando estabeleceu novas regras em relação ao patrimônio negociado para o casamento, agora quanto ao limite da meta a ser entregue para as mulheres:

89. Si quis coniogi suae metam dare voluerit, ita nobis iustum esse conparuit, ut ille, qui est iudex, debeat dare, si voluerit, in solidos quadringentos, amplius non, minus quomodo convenerit; et reliqui novilis homenis debeant dare in solidos trecentos, amplius non; et si quiscumque alter homo minus voluerit, quomodo convenerit. Et ipsa meta sub aestimatione fiat data et adpretiata, ut nullo tempore exinde intentionis aut causationis procedat. ${ }^{53}$

O capítulo 93 proibiu que fossem colocadas como juramentadoras de uma causa jurídica mulheres que estivessem submetidas ao mundium de outrem, revelando que tal instituto ia além da administração do patrimônio das mulheres, mas também influenciava a validade dos atos jurisdicionais entre os longobardos: "93. Si quis mulierem aut puellam aut religiosa femina, quae in alterius mundium est, in sacramento mittere presumpserit, conponat ad mundoald eius solidos numero quinquaginta, et in palatio sol. numero L. "54

No capítulo 94 foi estipulada a composição a ser paga por aqueles que levassem mulheres de suas casas sem o consentimento dos que exerciam o mundium. Procurou a norma distinguir a situação descrita de tirar de casa a mulher daquelas previstas nos capítulos 186, 187 e 191, do Edito de Rotário:

94. Si quis fream alienam sine volontatem de mundoald eius movere de casa, ubi inhabitat, presumpserit, et alibi duxerit, conponat ille, qui in caput est, pro inlecita presumptione ad mundoald eius solidos numero octonta. Et si liberi homenis cum ipso fuerent, conponat unusquis per caput solidos XX; servi autem in conpositione domini sui conpotentur. Nam si forte ille homo liber, qui ipsam fream de casa ubi est tolerit [et] sibi uxorem duxerit, sic conponat, sicut gloriose memorie rothari rex in anteriore edicto instituit. ${ }^{55}$

No ano de 728, observa-se que Liutprando novamente voltou a legislar sobre a situação patrimonial envolvendo as mulheres. O capítulo 100 prescreveu casos em que viúvas seriam

\footnotetext{
${ }^{53}$ Tradução livre: "89. Se alguém quer dar uma meta à sua mulher, a nós parece justo assim, que aquele que é juiz deve dar, se quiser, até quatrocentos sólidos, não mais; ou menos, quanto serão acordados. Os outros nobres devem dar até trezentos sólidos, não a mais; e se qualquer homem destes outros quer dar de menos, faça como forem acordados. A meta seja dada e apreciada segundo a estimação, para que não surja em nenhum momento uma disputa ou uma acusação."

${ }^{54}$ Tradução livre: "93. Se alguém ousa colocar em um juramento uma mulher, uma jovem ou uma religiosa que está sob o mundium de outro, pague ao mundoald dela uma composição de cinquenta sólidos e cinquenta sólidos ao palácio."

${ }^{55}$ Tradução livre: "94. Se alguém ousa levar embora da casa onde habita uma mulher livre de outrem, sem o consenso de seu mundoald, e a conduz para qualquer outra parte, aquele que é o chefe pague ao mundoald dela uma composição de oitenta sólidos pela ilícita pretensão. Se com ele estavam homens livres, paguem cada um uma composição de vinte sólidos por cabeça; os servos, em vez disso, sejam calculados na composição de seus patrões. Mas se, por acaso, aquele homem livre, que levou embora aquela mulher livre da casa onde estava, se a pega como mulher, pague a composição assim como instituído no precedente Edito pelo rei Rotário, de gloriosa memória."
} 
entregues para a vida monacal pelos que detinham do seu mundio para que estes pudessem se apropriar de seus bens. Por isso, a norma determinou procedimento para evitar casos de cupidez familiar:

\begin{abstract}
100. Nulli sit licentiam, qualevit mulierem, mundium eius habens in potestatem, post mortem mariti sui ante anni spacium velare aut monachico habito induere. Et si ipsa sua volontatem ante anni spacium hoc facere disposuerit, veniat ad palatium regi et dicat clementiae eius volontatem suam, et interrogata vel inquisita diligenter a rege, per eius permissum accipiat religiones velamen. Si vero ante anni spacium sine permissum regis quis hoc facere presumpserit, conponat regi wirigild suum; mundio vero mulieris, vel res eius propriae sint in potestatem palatii. Qui hoc ante anni spacium facere querit, propter logrum pecuniae vel seculi cupiditatem hoc facere querit, nam non ob amorem dei aut anima eius salvandam; quia post mortem viri sui, dum dolor recens est, in quale partem voluerit, animum eius inclinare potest. Nam cum in se revertitur, et carnis dilectatio ei obvenerit, quod peius est, in adulterium cadit, nec monacha esse invenitur nec laiga esse potest. Et si alter quiscumque homo, in cuius mundium non est, hoc facere presumserit, conponat wirigild suum in sagro palatium, et ipsa cum rebus suis sit in potestatem mundoaldi sui. ${ }^{56}$
\end{abstract}

No capítulo 101, se respeitada a norma supramencionada, foram estipulados os quinhões hereditários das mulheres que licitamente adotassem o véu da religião em um mosteiro. Quanto ao capítulo 103, novamente Liutprando proibiu a doação dos próprios bens à mulher em valor superior ao dia de núpcias como "metphio" e "mongengap", fazendo referência ao limite determinado no capítulo 7, de suas próprias leis.

No ano de 729, o capítulo 114 cuidou de excluir as mulheres que contraíssem núpcias de maneira ilícita da sucessão dos bens do marido morto, porquanto desrespeitariam a vontade dos seus parentes, que negligenciariam, por sua vez, a reivindicação justiça prevista no capítulo 189, do Edito de Rotário:

114. Si puella sine volontate parentum absconse ad maritum ambolaverit, et ei meta nec data nec promissa fuerit, et contegerit, ut maritus ipse antea moriatur, quam mundium de eam faciat, contenta sit ipsa mulier, nec possit postea metam querere ad heredibus eius, qui defunctus est, pro eo quod neclegenter sine

\footnotetext{
${ }^{56}$ Tradução livre: “100. A ninguém seja concedido pegar o véu ou vestir o hábito monacal em uma mulher da qual tinha o poder do mundium antes de um ano da morte de seu marido. Se aquela, por sua vontade, dispõe-se a fazer isso dentre um ano, venha ao palácio do rei e exponha o seu querer perante a sua clemência e, uma vez diligentemente interrogada e examinada pelo rei, pegue com sua permissão o véu da religião. Se, porém, alguém ousa fazer isso antes de um ano sem a permissão do rei, pague como composição ao rei o próprio wirigild; e o mundio da mulher e os seus bens pessoais fiquem em poder do palácio. Quem procura fazer isso antes de um ano procura fazê-lo por avidez ao dinheiro ou por concupiscência terrena e não por amor de Deus ou para salvar a sua alma; do momento em que, depois da morte de seu marido, enquanto a dor é recente, [ele] pode revelar na sua mente de que parte quer. Mas quando se recupera e ocorre o prazer pela carne e, coisas que são bem piores, cai em adultério, não é evidentemente monja nem pode ser laica. Se outro homem qualquer, sob cujo mundio ela não está, ousa fazer isto, pague como composição o próprio wirigild ao sacro palácio e ela, com os seus bens, fique em poder do seu mundoald."
} 
voluntatem parentum suorum ad maritum ambolavit, nec fuit, qui iustitiam eius exquirere. $^{57}$

Quanto às normas do ano de 731, salientou no proêmio que "Superstitiosae et vanae contentiones assidue nostram inpulsare clementiam non cessant. ${ }^{" 58}$ Tal fenômeno aponta para o fato de que a jurisdição régia era frequentemente invocada para a solução de causas. As palavras de Liutprando neste sentido parecem revelar fastídio ao apreciá-las, conclusão que se chega através da leitura das motivações de alguns dos novos capítulos, em que o rei demonstra estar empenhado em confirmar a validade das experiências jurídicas longobardas até então registradas.

Nessa perspectiva, o capítulo 119 ratificou a validade dos capítulos 178 e 189, 190 e 191, do Edito de Rotário, em relação ao patrimônio prometido para os esponsais e o prazo de validade do contrato de casamento, consolidando as informações já presentes nas normas longobardas do século VII, que colocavam as questões envolvendo mulheres e casamentos entre os assuntos de interesse especial do rei. $\mathrm{O}$ capítulo em comento também estipulou punição às mulheres que descumprissem o contrato antenupcial, proibindo-as de receber qualquer bens dos parentes, seja por herança ou por doação: "Quia excrevit vicium hoc in gentem nostram pro cupiditatem pecuniae, et ideo eum resegare volumus, ut inimicidias cessent et faida non habeant. ${ }^{, 59}$ Ao revés, se houvesse uma inimizade por causa de homicídio entre os parentes dos nubentes, então a mulher estaria absolvida se não fosse ao casamento, demonstrando, o próprio discurso jurídico, que a faida era prática reconhecida entre os súditos, desde que atendidas as regras para seu exercício.

O capítulo 120 também ratificou regulação jurídica anterior constituindo o que nos dias de hoje seria chamado de uma "típica norma de interpretação autêntica", porquanto explicou o que seria entendido por "maus-tratos" às mulheres em relação ao capítulo 182, do Edito de Rotário. Declara, deste modo, que a mulher não estaria obrigada a se casar com homem que não desejasse:

120. Contenit autem anterior edictus de fream suam, qui eam male tractaverit, ut amittat mundium ipsius; et non dicit, qualis sit ipsa mala tractatio. Proinde providimus dicere, qualis a ipsa sit mala tractatio, id est si eam fame negaverit, aut vestimentum vel calciamentum secundum qualitatem pecuniae non dederit, aut ad servum vel haldionem alterius eam oxorem dare presumpserit, aut eam battederit turpiter, excepto si infans fuerit, pro honesta disciplina ostendendum muliebre opera aut ad vicium malum emendandum, sicut de propriam filiam suam. Et si eam in indicebilem operam quoacta minaverit, aut si ipsa adulteraverit: omnia haec, qui facere presumpserit, male tractata esse dicimus.

\footnotetext{
${ }^{57} 114$. Se uma jovem vai ao marido escondida sem o conhecimento dos parentes e a ela não for dada nem prometida uma meta e acontece que o marido morre antes de conseguir o mundium sobre ela, a mulher permaneça satisfeita e não possa pedir depois a meta aos herdeiros daquele que está morto, porque foi ao marido sem cuidar do consentimento dos seus parentes; e não foram reivindicar justiça por ela.

${ }^{58}$ Controvertidas superstições e vaidades não cessam de incomodar assiduamente nossa clemência.

${ }^{59}$ Tradução livre: "Isto porque tal vício se desenvolveu na nossa estirpe pela cupidez de dinheiro e por isso queremos reprimi-lo, para que cessem as inimizades e não haja faida."
} 
Insuper et addimus, ut nec ad liberûs homenis eam ad maritum absque eius volontatem dare presumat, quia peius tractata esse non potest, si illum verum tollit, quem ipsa non vult. Ideo statuimus, ut propter plagas et feritas, si fecerit, vel de adulterium, conponat eidem feminae, sicut edictus contenit, et mundium eius amittat. $^{60}$

O capítulo 121 cuidou de manter a tutela da tradicional honra do marido cuja mulher tivesse sido tocada com impudicícia por outrem, determinando que este pagasse o próprio wergild como composição. Tratando-se apenas de uma suspeita, o caso seria então resolvido por meio de juramento ou duelo. Quanto à mulher que consentisse ser tocada, o marido poderia exercer a vingança sobre ela, através de violência fisica ou mesmo vendendo-a, sendo vedado, contudo, matála ou a mutilar:

\begin{abstract}
121. Si quis admodum inventus fuerit cum oxorem alienam torpiter conversari, id est si manos in seno aut ad pectum eius miserit vel ad alium locum, unde turpe esse potest, cum consensum ipsius mulieris, et provatum fuerit, conponat, qui hoc malum penetravit, wirigild suum ad maritum ipsius mulieris. Si autem causa non fuerit provata, nisi tantummodo quispiam de suspecto alium de oxorem suam conpellaverit, habeat licentiam ipse, qui conpellat, aut ad pugna aut ad sagramentum ipsum hominem querere, qualis voluerit. Si vero ipsa mulier in hac inlecita causam consentiens fuerit, potestatem habeat maritus eius, in eam vindicta dare, sibi in disciplina, sibi in vindicionem, ubi voluerit; verumtamen non occidatur, nec ei sematio corporis fiat. Si quidem forsitans talis fuerit ipse liber homo, ut non habeat, unde conpositionem faciat, tunc puplicus deveat eos dare in manu mariti eius, et ipse in eum faciat vindictam: in disciplinam et in vindicionem, nam non in occisionem aut in semantionem. $[\ldots . .]^{61}$
\end{abstract}

Na mesma linha de raciocínio do capítulo anterior e com aparência de uma mitigação à punição de morte à mulher prevista nos capítulos 211 e 212 do Edito de Rotário, o rei Liutprando,

\footnotetext{
${ }^{60}$ Tradução livre: "120. O Edito anterior contém também que aquele que trata mal uma sua livre perca o seu mundium, mas não diz qual é este mal modo de tratá-la. Por isto previmos a dizer qual seja este mal modo de tratála: se a deixa morrer de fome, ou não lhe dá vestimentas ou calçado segundo sua possibilidade econômica, ou se ousa dá-la como mulher a um servo ou a um aldius alheio, ou se lhe bate de modo desonroso, exceto se é uma criança, para impor-lhe uma educação honesta em relação aos trabalhos femininos, ou para corrigi-la de maus vícios, como se fosse sua própria filha, se a constrange a qualquer trabalho indizível ou se comete adultério com ela. [Se] alguém ousa fazer todas essas coisas, dizemos que é tratada mal. Acrescentamos ainda que não ouse nem mesmo dá-la a um homem livre sem o seu consenso, porque não pode ser tratada pior que ser realmente pega por aquele a quem não quer. Por isso, estabelecemos que pague a composição para aquela mulher pelas feridas ou lesões, se as fizer, ou pelo adultério, assim como contido no Edito, e perca o seu mundium."

${ }^{61}$ Tradução livre: 121. Se alguém for incontestavelmente encontrado comportando-se de modo desonroso com a mulher de outro, isto é, que lhe coloca as mãos no seio ou sobre o peito ou outro lugar que possa ser desonroso, com o consenso da mulher, e isto for provado, aquele que cometeu aquela má ação pague como composição o próprio wirgild ao marido da mulher. Se, ao contrário, a causa não for provada, mas simplesmente alguém, tendo suspeita, acusa outro de ter agido assim com sua mulher, aquele que acusa tenha licença de chamar aquele homem ao duelo ou juramento, como quiser. Se depois a mulher estiver consentido àquela ação ilícita, seu marido tenha faculdade de exercitar a vingança sobre ela, ou com uma punição disciplinar ou vendendo-a onde quiser; mas não a mate, nem lhe faça uma mutilação corporal. Se, por acaso, aquele homem livre é tal que não pode pagar a composição, então a autoridade pública deve entregá-lo nas mãos do marido dela e este exerça a vingança sobre ele, com uma punição disciplinar ou vendendo-o, mas não o matando ou mutilando-o. [...]"
} 
no capítulo 122, de suas normas, revelou ironia ao considerar um homem que contraísse casamento com mulher já casada como se fosse um tolo:

122. Si quis miser insipiens homo presumpserit sponsare mulierem habentem virum, sibe ipse vir eius egroto sit sibe sanus, sicut modo et nobis talem causam adnuntiatam est, et provatum fuerit, conponat ipse, qui hoc fecerit, wirigild suum ad maritum eius; et ipsa suscipiat in se talem condemnationem, qualem superius diximus de illam mulierem, qui se turpiter adtractare permittit. ${ }^{62}$

O capítulo 123 estipulou os valores das composições a serem pagas nos casos em que pessoas fossem envolvidas em um tumulto, ficando evidenciado que as lesões às mulheres, nesse caso, seriam equivalentes aos dos homens: “[...] conponat medietatem pretii ipsius masculi, tamquam si eum occidissit, et de feminas semilem modo medietatem pretii, tamquam si fratrem eius occidissit; [...]." 63

O capítulo 125 fixou as composições que deveriam ser pagas aos que ofendessem as mulheres livres em situações em que elas não poderiam oferecer resistência:

125. Si quis malitiosae et per superbia, sicut et modo factum esse cognovimus, mulierem aut puellam liberam sedentem ad necessitatem corporis sui, vel in alium locum, ubi ipsa femina pro sua necessitatem nuda esse vedetur, pungere vel percutere presumpserit, conponat ad mundoald eius solidos octuagenta; $[\ldots]^{64}$

O capítulo 127 estabeleceu a situação jurídica da viúva de um romano (bizantino), cujos filhos seguiriam as regulações jurídicas romanas, como o pai, impedindo que os parentes longobardos da viúva repristinassem o mundium sobre ela e exercessem a vingança contra o novo marido:

127. Si quis romanus homo mulierem langobardam tolerit, et mundium ex ea fecerit, et post eius decessum ad alium ambolaverit maritum sine volontatem heredum prioris mariti, faida et anagrip non requiratur. quia posteûs romanum maritum se copolavit, et ipse ex ea mundio fecit, romana effecta est, et filii, qui de eo matrimonio nascuntur, secundum legem patris romani fiunt et legem patris

\footnotetext{
${ }^{62}$ Tradução livre: "122. Se um pobre tolo ousa contrair os esponsais com uma mulher que já tem um homem, seja este seu homem doente ou são, assim como apenas referido como tal causa, e isto for provado, aquele que faz isto pague como composição o próprio wirigild ao marido dela; e ela submeta-se à condenação que dissemos supra pela mulher que consente em ser tratada de modo desonroso."

${ }^{63}$ Tradução livre: "[...] pague como composição, se é masculino, a metade do valor que deveria pagar se o tivesse assassinado; e se é uma feminina, igualmente a metade do valor que deveria pagar se tivesse matado um seu irmão; $[\ldots] "$

${ }^{64}$ Tradução livre: "125. Se alguém, como apenas ficamos sabendo, com malícia e soberbia ousa soquear ou bater em uma mulher, ou uma jovem, livre, que está sentada pelas suas necessidades corporais ou em qualquer outro lugar onde esteja nua por necessidade, pague como composição ao seu mundoald uma composição de oitenta sólidos; [...]"
} 
vivunt; ideo faida et anagrip menime conponere devit, qui eam postea tolit, sicut nec de alia romana. ${ }^{65}$

O capítulo 129, bastante extenso, relatou uma situação jurídica que estaria incomodando o rei, que seriam mulheres declarando-se casadas com crianças menores de 12 anos completos, o que não era permitido. Por tal motivo Liutprando proibiu tais casamentos, salvo se os pais ou avós da criança já tivessem permitido a união. Mesmo assim, se esses adultos morressem antes da criança atingir a idade, a mulher não poderia ser unir ao menor e, se o fizesse, a união não seria válida e deveriam ser separados. Quanto às demais consequências jurídicas:

[...] Femina vero ipsa revertatur vacua cum obproprium suum et non habeat potestatem alio viro se copolare, dum ipse puerolus ad aetatem suprascripta pervenerit. Siquidem ipsa inpleta etatem puer ipse sibi eam oxorem habere voluerit, habeat licentiam, et si eam noluerit, tollat sibi oxorem aliam, qualem voluerit aut potuerit. Illa vero, si ad alium maritum ambolaverit, et ipse puerolus eam habere noluerit, non ei possit vir suus, qui eam tollit, pleniter metfio dare, sicut ad aliam puellam, sed tantumodo mediaetatem, sicut ad viduam mulierem. Qui verum puerum ipsum soaserit, sibe parentis eius sint, sibe extraneus homo, conponat solidûs centum, medietatem regi et medietatem ad ipsum puerolum. ${ }^{66}$

Nas normas do ano de 733, vai ficando cada vez mais claro o discurso jurisprudencial por parte de Liutprando, com extensas escritas e justificativas para as decisões, surgindo situações que contextualizam o cotidiano da vida privada na Itália Alto-medieval.

No capítulo 130 foi estabelecido que os homens que oferecessem as próprias mulheres para conjunção carnal com outrem, a mulher deveria ser morta, segundo o disposto no capítulo 212, do Edito de Rotário, porque o adultério não poderia ficar ocultado, comprovando que as causas envolvendo família eram tidas como de interesse do rei, ou seja, causas "públicas". No tocante ao homem que desse seu consentimento à sua mulher, então deveria pagar uma composição aos parentes dela, conforme expressa menção ao capítulo 378, do Edito de Rotário, ou seja, pagar o wergild por ela e a proibição de ficar com seus bens; e o homem que cometesse o adultério com ela deveria ser entregue aos parentes dela, mas não ao marido, para o exercício da vingança. No caso

\footnotetext{
65 Tradução livre: "127. Se um homem romano pega uma mulher longobarda e adquire o mundium sobre ela e depois da morte dele vai a outro marido sem o consenso daqueles herdeiros do primeiro marido, não procurem a faida e o anagrip, porque, depois que se uniu a um marido romano e depois que ele adquiriu o mundium sobre ela, tornou-se uma romana e os filhos que nasceram de tal matrimônio são romanos segundo a lei do pai e vivem segundo a lei do pai. Por isso, quem depois a pega não deve pagar a composição pela faida e pelo anagrip, assim como não por outra romana."

${ }^{66}$ Tradução livre: “[...] A mulher retorne sem nada, [fique] com sua vergonha e não tenha faculdade de unir-se a outro homem até que a criança atinja a idade supra escrita. Se, completa aquela idade, a criança quer tê-la como mulher, tenha a licença; e se não quer, pegue outra mulher, aquela que quiser ou puder. Em relação à lei, se vai a outro marido e a criança não quer tê-la, o seu homem, aquele que a pega, não possa dar-lhe inteiramente a metfio, como para outra jovem, mas somente a metade como para uma mulher viúva. Aquele que convenceu a criança, seja um seu parente, seja um estranho, pague uma composição de cem sólidos, metade ao rei e metade à criança."
} 
de ocorrer a sugestão do marido, mas a mulher refutasse a proposta, então esse deveria pagar uma composição à semelhança do estatuído no capítulo 72, das Leis de Liutprando.

Em relação ao capítulo 135, sua redação revela o modo consuetudinário de resolução de conflitos baseado na vingança entre os germânicos e uma suposto conselho de prudência do rei para seus súditos evitarem a violência:

\begin{abstract}
135. Adnuntiatum est quidem nobis, quod aliquis perversus homo, dum se quedam femina in fluvio lavarit, pannûs eius, quos ibi habuit, totûs tolissit, et ipsa remansissit nuda, et qui ibant ei transiebant per locum illum, pro peccatis vedebant turpitudinem eius; ipsa autem in ipso fluvio semper stare non potuebat, revertere autem ad casam suam nuda erubiscibat. Proinde statuimus, qui talem inlecita presumptionem fecerit, conponat eidem femine, cui talem turpitudinem fecit, ipse wirigild suum. Ideo hoc dicemus, quia si invenissit eum aut frater aut vir aut propinquus parentis eiusdem feminae, scandalum cum eum comittere habuit, et qui superare potuissit, unus alterum interficere habuit. Propterea melius est, ut se vivo conponat wirigild suum, quam de mortuo crescat faida inter parentis, et conpositio maior. ${ }^{67}$
\end{abstract}

No ano de 734, a análise do discurso do capítulo 141 permite o argumento de que as leges Langobardorum não seriam meros monumentos jurídicos para ornar a coroa régia dos poderes seculares com a imitatio imperii nos moldes romanos, mas revela uma regulamentação normativa contemporânea aos fatos que ocorriam na sociedade longobarda do século VIII. Com efeito, em tal capítulo há o relato de que homens, com o fim de não se sujeitarem ao pagamento da composição prevista no Edito de Rotário pela liderança em ataque à mão armada - capítulo 19 -, estariam reunindo mulheres armadas para atacarem homens em menor quantidade e com requintes de crueldade superiores aos praticados por homens. Liutprando permitiu o uso da força contra as mulheres em tal situação, isentando os homens de pagarem composições pelas mulheres feridas ou mortas. Ademais, se alguma delas fosse capturada pela autoridade pública, o preposto do rei deveria aplicar punição corporal infamante com o escopo declarado de exemplaridade e, ainda, seus maridos deveriam pagar as composições às pessoas que fossem ofendidas pela conduta de suas mulheres, porque atos de reunião e sedição seriam tipicos de homens e não de mulheres. Por fim, se uma

\footnotetext{
67 Tradução livre: “135. Fazemos referência a um homem perverso que, enquanto uma mulher se lavava no rio, pega-lhe todas as roupas que estavam ali, e ela fica nua e quem andava e vinha para aquele lugar via de modo pecaminoso a sua vergonha. Aquela, de resto, não poderia ficar sempre dentro do rio e de outra parte se envergonhava de retornar nua para casa. Por isso estabelecemos que quem comete uma similar impudica ilicitude pague como composição para a mulher contra a qual cometeu um tal ato vergonhoso o seu wirigild. Dizemos isto porque, se tivesse encontrado o irmão ou o marido ou um parente próximo daquela mulher, teria explodido um tumulto com ele e aquele que tivesse prevalecido mataria o outro. Por isso, é melhor que se pague como composição o próprio wirigild enquanto vivo, antes que de sua morte nasça uma faida entre parentes e uma composição maior."
} 
mulher concorresse sozinha a um tumulto, então o rei determinou que fosse observado o capítulo 378, do Edito de Rotário.

141. Relatum est nobis, quod aliqui hominis perfidi et in malitia astuti, dum per se non presumpsessent mano forti aut violento ordinem intrare in vicum aut in casam alienam, timentes illam conpositionem, que in antiquo edicto posita est, fecerunt collegere mulieres suas, quascumque habuerunt, liberas et ancillas, et miserunt eas super homines, qui minorem habebant virtute, et adprehendentes hominis de ipso loco et plagas fecerunt, et reliqua mala violento ordine plus crudeliter quam viri exercuerunt. Dum autem hoc ad nos pervenissit, et ipsi homines pro sua violentia, qui minus potebant, interpellabant: ita prospeximus in hoc edicto adfigere: ut si amodo mulieres hoc facere in qualecumque locum presumpserit, primum omnium decernimus, ut si aliqua iniura aut obprobrium, aut plagas aut feritas, aut mortem ibi acceperint, nihil ad ipsas mulieres aut ad viros aut ad mundoald earum conponant illi, qui se defendendum eis aliqua fecerint lesionem aut internicionem. Insuper et publicus, in quo loco factum fuerit, conprehendat ipsas mulieres, et faciat eas decalvare et frustare per vicos vicinantes ipsius loci, ut de cetero mulieres tale malitia facere non presumant. Et si in ipsa causa feritas aut plagas fecerint ipsae mulieres cuicumque homini, mariti earum conponant ipsas plagas aut feritas, quas ipsae fecerunt, secundum edicti tinore. Hoc autem ideo prospeximus tam de disciplina quam de conpositione, quia non potuimus mulierum collectionem ad harschild consimilare, neque ad seditionem rusticanorum, quia istas causas viri faciunt, nam non mulieres: ideoque sic de ipsis mulieribus faciat, sicut supra statuimus. Si quidem simpliciter in scandalum qualiscumque mulier cocurrerit, et mortem aut plagam aut feritam ibi susceperit, sic ei faciat iustitiam, sicut decessor noster rothari rex instituit et iudicavit. ${ }^{68}$

O último ano de registro de normas jurídicas por Liutprando foi em 735 e, em relação às mulheres, acrescentou somente um capítulo, que é o 146, em que procurou regulamentar os casos em que uma mulher ou jovem fossem encontradas andando em campo alheio causando danos à semeadura. Em tal situação o proprietário das terras poderia pegá-la como penhor para receber seis

\footnotetext{
${ }^{68} 141$. Referimo-nos que alguns homens pérfidos e dotados de uma astuta malícia, não ousando por si de entrar à mão armada ou com a força em uma aldeia ou em uma casa de outrem, temendo a composição prevista no antigo Edito, fazem ajuntarem-se suas mulheres, quantas possuírem, e as mandam contra os homens que estão em menor força; pegam os homens daquele lugar, infligem neles feridas e outros males com violência, com maior crueldade do que fazem os homens. Por que estas cousas foram trazidas a nós e aqueles homens mais enfraquecidos moveram uma acusação por aquela violência, providenciamos acrescentar neste Edito que se no futuro mulheres ousarem fazer uma coisa do gênero em qualquer lugar, antes de tudo estabelecemos que se acolá receberem uma qualquer violência ou ultraje, ou lesões ou feridas, ou também a morte, aqueles que fizerem nelas algum dano ou que as assassinarem para defenderem-se não paguem nenhuma composição àquelas mulheres ou aos seus homens ou aos seus mundoald. Ainda, a autoridade pública preposta naquele lugar que isto aconteceu pegue aquelas mulheres e lhes faça escalpo e açoite-as pelas aldeias vizinhas daquele lugar, de modo que no futuro as mulheres não ousem cometer uma similar malvadeza. Se naquela circunstância aquelas mulheres provocaram lesões ou feridas a qualquer homem, os seus maridos paguem a composição por tais feridas ou lesões, que elas provocaram, segundo o teor do Edito. Estabelecemos isto, seja em relação à punição seja em relação à composição, para que não possam assimilar uma reunião de mulheres ao harschild e nem a uma sedição de camponeses, do momento em que estas coisas se fazem aos homens, não às mulheres; por isso se faça destas mulheres assim como estabelecemos supra. Se uma mulher concorre sozinha a um tumulto e recebe a morte ou uma ferida ou lesão, faça-se justiça como estabelecido e julgado pelo nosso predecessor Rotário.
} 
sólidos como composição. Mas se a mulher fosse detida, então quem a prendeu deveria pagar a composição de cem sólidos, metade ao rei e metade ao que possuisse o mundium. Chama a atenção o dispositivo normativo que já previa a malícia de quem, ávido pela composição, poderia constranger a sua mulher a caminhar em um campo alheio com intuito de buscar uma composição em caso de aprisionamento ilícito:

146. Si quis invenerit libera mulierem aut puellam per campum suum seminatum ambolantem et viam indicantem, pignerit eam, et parentes aut mundoald eius conponant pro ipsa solidos sex, sicut lex est; nam si ipsa conprehendere presumpserit et ad casam suam legatam aut submanicatam duxerit, conponat solidos centum, medietatem regi et medietatem, cuius causa est; sic tamen, ut conpositio illa de sex solidis in ipsa conpositione conputetur. Et si pulsatus fuerit ille, in cuius mundio fuerit mulier aut puella, quod asto et iniquo animo feminam ipsam ambulare per laborem alterius fecissit, ut ei conponerit: tunc preveat sacramentum, quod cupiditatem habendum de conpositionem ipsam asto animo per laborem ipsius ipsa femina non ambulassit, nec damnum asto faciendum. Et si iuraverit, tunc ipse qui eam conprehendere presumpserit, conponat solidos centum, ut supra; et si iurare non presumpserit, parentes aut mundoald ipsius feminae, ut supra dictum est, conponat solidos sex pro via indicata, sicut supra diximus, et ille qui conprehensit, sit solutus. ${ }^{69}$

\section{As mulheres nas Leis de Ratchis}

Após a morte de Litprando, em 744, seu sobrinho Ildeprando reinou sozinho por poucos meses, sendo vítima de uma conspiração de duques longobardos que colocaram Ratchis - do ducado de Friuli - no trono. Este reinou entre 744 até 749 e durante esse período foram acrescentados catorze novos capítulos ao corpo das Leges Langobardarum, provavelmente todos do ano 745 (Cf. AZZARA; GASPARRI, 2005, p. 276) .

Somente o capítulo 6 que tratou sobre tutela jurídica de mulheres, onde o rei procurou regularizar a situação das que se uniram a servos e que deveriam ser reduzidas à escravidão na forma do capítulo 221, do Edito de Rotário e capítulo 24, das Leis de Litprando, mas que não tivessem sido descobertas no prazo de sessenta anos desde a data da união proibida. Assim, passado

\footnotetext{
${ }^{69}$ Tradução livre: "146. Se alguém encontra uma mulher, ou uma jovem livre, que anda por um seu campo semeado e que deixa rastro, pegue ela em penhor e os seus parentes, ou seu mundoald, paguem como composição por ela seis sólidos, como prevê a lei; mas se ousa capturá-la e levá-la para casa, amarrada ou manietada, pague uma composição de cem solidus, metade ao rei e metade àquele que é chamado à causa, de modo tal que a composição de seis sólidos seja calculada dentro desta composição. Se aquele sob cujo mundium se encontra a mulher ou jovem for acusado de ter feito caminhar intencionalmente a mulher sobre um campo alheio trabalhado e com finalidades iníquas, então preste juramento de que a mulher não caminhou sobre o campo trabalhado daquele intencionalmente, por cupidez da composição, nem para provocar intencionalmente um dano. Se jura, então aquele que ousa capturá-la pague a composição de cem solidus, como supra; se, ao contrário, não ousa jurar, os parentes ou mundoald da mulher, como se diz supra, paguem uma composição de seis sólidos para levá-la embora, como dissemos supra, e aquele que a capturou seja absolvido."
} 
esse prazo, seria garantida a liberdade delas e de seus descendentes, com a ressalva de que se no futuro um servo pegasse uma $\operatorname{arimana}^{70}$, então ela seria submetida à servidão:

6. Reminiscimus enim, quia anterior edictus contenere dignoscitur de liberis feminis, qui servis copulantur, ut quandoque inventi essent, in servitio reducerentur. Sed quia grimowald rex instituit de his, qui per triginta annos in libertatem viverent, ut in servitio non replicarentur, tamen, quia curtes regia possessio non inpedit nisi per sexaginta annorum curricula, sicut domnus liutprand rex instituit, ideo definivimus: si quae feminae admodum inventae fuerint, que sibi servi copulaverunt et per sexaginta annos in libertatem permanserunt, ipse aut filii vel filiae earum, aut qui de ipsis procreati inventi fuerint, nullus eos in servitio replicare presumat, sed in libertatem suam permaneant, sicut per sexaginta annos permanserunt. Si autem amodo presumpserit cuiuscumque servus arimanna ducere uxorem, sic exinde detur iudicium, sicut anterior pagina edictus continetur. ${ }^{71}$

\section{As mulheres nas Leis de Astolfo}

O rei Astolfo (749-756) determinou o acréscimo de 22 novos capítulos no corpo normativo do reino longobardo, tornando-se o último rei legislador da estirpe, porquanto seu sucessor, Desidério, não editou nenhuma norma que tenha sido registrada e passada à posteridade.

No capítulo 13 foi estendido às filhas a possibilidade da entrega de bens como se fossem filhos, mostrando uma clara melhora na condição patrimonial das mulheres:

13. A nostris decessoribus iam antea est institutum, ut langobardus potestatem habeat filium suum sibi bene servientem de rebus suis meliorare; de filiabus non contenebatur. Ideo statuimus, ut si duas filias habuerit et filium non reliquerit, potestas ei sit unam filiam suam, qualem voluerit, meliorare tertia parte rerum suarum; si tres fuerint, quarta; et si amplius fuerint, per hanc rationem conputetur.

14. Si quis langobardus decidens uxori suae usumfructum de rebus suis iudicare voluerit et filiûs vel filias ex ea reliquerit, non amplius ei pro usumfructum iudicare possit quam medietatem ex sua substantia super illut, quod ei in morgincap et metam secundum legem datum fuerit. Et si filiûs aut filias ex alia uxore reliquerit unum aut duos, possit uxori suae tertiam portionem ad usumfructum relinquere; si fuerint tres, quartam partem; si amplius, per eo

\footnotetext{
${ }^{70}$ Mulher livre longobarda, mas sempre submetida ao mundium de um homem livre da estirpe.

${ }^{71}$ Tradução livre: " 6 . Recordamos que o Edito precedente contém conhecido dispositivo em relação às mulheres livres que se unem com servos, que quando forem descobertas sejam reduzidas à servidão. Mas porque o rei Grimoaldo instituiu a respeito daqueles que vivem em liberdade por trinta anos que não sejam dados de novo à servidão, e porque, por outro lado, o possuidor não contrasta com a corte régia senão depois de um período de sessenta anos, como estabeleceu o rei e senhor Liutprando, assim definimos: se se descobre, de fato, as mulheres que se uniram a servos e permaneceram em liberdade por sessenta anos, eles mesmos, ou seus filhos, ou filhas, ou quantos forem reconhecidos como descendentes deles, ninguém ouse torná-los servos, mas conservem sua liberdade assim como conservaram por sessenta anos. Se, em vez disso, no futuro um servo de qualquer um ousar pegar como mulher uma mulher arimana, o juízo processa sucessivamente como contido nas páginas do Edito anterior."
} 
numero conputetur. morgincap et meta, quod ei legibus data est, habeat inantea. Si quidem nupserit postea aut mortua fuerit, usumfructum in integrum ad heredes revertatur, de meta vero et morgincap fiat secundum anteriore edictum. ${ }^{72}$

No capítulo 14 Astolfo permitiu que as mulheres fossem herdeiras de maior quinhão por parte dos maridos mortos, mas estabeleceu um limite, da mesma forma como havia feito os reis predecessores. Em relação à parte final do capítulo, a referência seria aos capítulos 182, 183 e 199, do Edito de Rotário.

\section{Conclusão}

O objetivo da pesquisa foi verificar como se contextualizam aspectos da condição jurídica das mulheres no âmbito das leis do reino longobardo e quais mecanismos de tutela jurídica foram declarados pelos detentores do poder na época em relação a estas.

Diferentemente das fontes literárias do período, que revelam por vezes elementos do imaginário místico das mulheres, e de outras narrativas históricas, como aquelas envolvendo a rainha Teodolinda no crepúsculo do século VI, as fontes jurídicas primárias indicam a inexistência de uma situação de igualdade para com os homens. Nesta perspectiva, o tratamento jurídico concedido às mulheres fazia com que estas fossem consideradas como um objeto de negócio jurídico, especialmente nos acordos pecuniários em relação ao domínio do mundium e sua entrega ao marido conforme o instituto romano da traditio.

Quanto ao Edito de Rotário, tal complexo normativo é considerado entre os mais representativos dos costumes germânicos no âmbito das normas escritas na Alta Idade Média. Este, antes de apontar para um protagonismo feminino do âmbito jurídico, revela a submissão forçada às mais violentas práticas punitivas no caso de atentados contra os interesses daquela sociedade de matriz eminentemente patriarcal. As normas encontradas regendo aspectos jurídicos da vida feminina foram emanadas, portanto, para serem funcionais à regulamentação de particularidades patrimoniais, como aquelas presentes nos contratos de casamento, e, nos casos em que as mulheres

\footnotetext{
72 Tradução livre: "13. Já foi estabelecido por nossos predecessores que um longobardo tenha a faculdade de dar os melhores dos seus bens ao filho que o serve bem, mas não se diz nada das filhas. Por isso decretamos que se possui duas filhas e não tenha nenhum filho, tenha a faculdade de dar um terço de seus bens a uma de suas filhas, àquela que quiser; se são três, um quarto; se são mais, calcule-se segundo esta proporção. [...] 14. Se um longobardo moribundo quer destinar para sua mulher o usufruto de seus bens e deixa filhos dela, não possa destinar como usufruto mais da metade do seu patrimônio além daquele que deu segundo a lei como morgincap e como meta. Se deixa um ou dois filhos, ou filhas de outra mulher, possa deixar como usufruto para sua mulher um terço; se são três, um quarto; se são mais, calcule-se segundo aquele cômputo. [Ela] tenha além do morgincap e da meta que foram dadas pela lei. Se depois se casa novamente ou morre, o usufruto retorne integralmente aos herdeiros, mas em relação à meta e ao morgincap, regule-se segundo o Edito anterior."
} 
fossem ofendidas em situações de vulnerabilidade, amiúde os seus representantes masculinos é que receberiam as compensações pecuniárias extintivas da punibilidade.

$\mathrm{O}$ advendo do cristianismo de vertente católica entre os reis longobardos parece ter trazido como efeito um ambiente favorável ao surgimento de novos e melhores mecanismos de tutela jurídica às mulheres, permitindo, por exemplo, que as repudiadas fossem recebidas novamente pela família ou pela corte régia e que as acusadas sem causa legítima tivessem como oferecer defesa judicial por parte dos parentes. O capítulo 8 das Leis de Grimoaldo certamente permite vislumbrar situações do cotidiano da vida doméstica dos germânicos longobardos, justificando o uso das fontes primárias como objeto de análise.

Em relação às demais, as Leis de Liutprando revelam mudanças significativas no conjunto de mecanismos de tutela jurídica das mulheres até então existente no reino longobardo. Grande parte destas é fruto da firme adesão de Liutprando à doutrina católica, que passa a fomentar um movimento de incorporação na cultura jurídica longobarda de elementos desta última provenientes, em particular em assuntos vinculados a temas morais e religiosos. Com efeito, o resultado da análise das normas editadas ao longo de seu reinado apontam para a busca de uma possível equiparação entre homens e mulheres no campo dos direitos sucessórios; a proteção do patrimônio das mulheres; a tomada em consideração da opinião das mulheres sobre a venda de seus bens; a proteção dos interesses da mulher no casamento; a mitigação a determinadas punições etc.. É de particular relevo, neste âmbito, o já mencionado capítulo 120 , em que subsiste uma tentativa de disciplinar casos de "maus-tratos" à mulher em favor de sua proteção.

A norma em referência às mulheres livres emanada no período do rei Ratchis, por outro lado, buscava anistiar àquelas que estavam para ser reduzidas à escravidão devido ao fato de terem se unido a um servo, como tinha sido anteriormente estipulado nas normas por Rotário e por Liutprando. Embora o prazo de sessenta anos possa ser considerado bastante amplo, a nova norma certamente se apresenta como mais benéfica.

Finalmente, no que se refere às Leis de Astolfo, a ampliação da tutela jurídica se apresenta através de benefício concedido às filhas, que passam a ter um aumento na proporção de doação de bens, assim como houve aumento no quinhão que uma viúva poderia receber pelo evento da morte de seu marido.

A Análise do discurso jurídico das normas longobardas dos séculos VII e VIII nos conduz a algumas conclusões interessantes sobre o tema deste ensaio. A primeira entre essas concerne ao impacto da transformação da sociedade guerreira dos germânicos em cristãos católicos, ou seja, através de elementos advindos da doutrina católica, houve uma crescente ampliação na tutela jurídica dos interesses das mulheres. Se em um primeiro momento eram enquadradas mais como 
um objeto negociável entre os longobardos detentores do mundium, através da sempre maior influência da doutrina da Igreja Católica em alguns institutos jurídicos longobardos, passaram a receber reconhecimento da situação de vulnerabilidade ao qual estavam submetidas. É deste modo que surgem novas normas em prol da proteção de seus interesses; mas sem que com isso ocorresse um rompimento na considerável distinção entre as prerrogativas jurídicas dos homens em relação às mulheres, que jamais teriam tido tratamento isonômico durante a existência do Reino dos Longobardos.

\section{LONGOBARD GERMANIC LAW IN THE 7TH AND 8TH CENTURIES: LEGAL TUTELA UPON FREE WOMEN IN ITALIAN CULTURE DURING THE EARLY MIDDLE AGES}

ABSTRACT: The objective of the present work is to analyse the Ancient Germanic Law discourse within the Leges Langobardorum primary sources, written in the VII and VIII centuries in Early Medieval Italy, seeking to understand possible mechanism of the Legal Tutelae that dealt specifically with women. This research uses the inductive approach in a historical method. This article theoretical framework harmonises with Foucault's archaeology. The results indicate that women with a Germanic strain in the Longobard Kingdom were not absorbed in a mystical imagery nor were they in a situation of isonomia in relation to men. They were, although, frequently treated with trade purposes by those with mundium powers upon them. The article concludes that, as the Catholicism influence on the kings of Longobard strain raised, there had been an increasingly increment on rules aiming to protect women's vulnerabilities, whether diminishing the severity of punishments or protecting property interests.

Keywords: Women. Legal Tutela. Longobard Kingdom. Early Middle Ages. Leges Langobardorum.

\section{REFERÊNCIAS BIBLIOGRÁFICAS}

ALVES, Rubem. Filosofia da ciência: introdução ao jogo e a suas regras. São Paulo: Edições Loyola, 2002.

AZZARA, Claudio; GASPARRI, Stefano (Org.). Le leggi dei longobardi: storia, memoria e diritto di un popolo germanico. Roma: Viella, 2005.

BARK, Willian Carroll. Origens da idade média. Rio de Janeiro: Zahar, 1979. 
BATISTA, Nilo. Matrizes ibéricas do sistema penal brasileiro, I. Rio de Janeiro: Revan/ICC, 2002.

BOGNETTI, Gian Piero. S. Maria Foris Portas di Castelseprio e la Storia Religiosa dei Longobardi. In. L'età longobarda. Milano: Giufrè, 1966, 2.v.

- L'Editto di Rotari come espediente politico di una monarchia barbarica. In. L'eta longobarda. Milano: Giuffrè, 1967, 4.v.

BRUNNER, Heinrich. Historia del derecho germánico. Barcelona: Labor, 1936.

BURKE, Peter. A escrita na história: novas perspectivas. São Paulo: Unesp, 1992.

CALASSO, Francesco. Medioevo del diritto: le fonti. Milano: Giuffrè, 1954.

CARBASSE, Jean-Marie. Histoire du droit pénal et de la justice criminelle. Paris: Universitaires de France: 2000.

CAVANNA, Adriano. Nuovi problemi intorno alle fonti dell'editto di rotari. In: Scritti. Napoli: Jovene, 2007. 1.v.

CERVO, Amado Luiz; BERVIAN, Pedro Alcino. Metodologia cientifica: para uso dos estudantes universitários. São Paulo: McGraw do Brasil, 1976.

DIACONO, Paolo. Storia dei longobardi. Milano: Lorenzo Valla/Mondadori, 2008. 
FOUCAULT, Michel. Arqueologia do saber. Rio de Janeiro: Forense Universitária, 2000.

HESPANHA, António Manuel. Justiça e litigiosidade: história e prospectiva. Lisboa: Fundação Calouste Gulbenkian, s.d.

JARNUT, Jörg. Storia dei longobardi. Torino: Einaudi, 2002.

KRAMER, Heirich; SPRENGER, James. O martelo das feiticeiras: Malleus maleficarum. 17a Ed. Rio de Janeiro: Rosa dos Tempos, 2004.

MERÊA, Paulo. Estudos de direito visigótico. Coimbra: Atlântida, 1948.

MEZZAROBA, Orides; MONTEIRO, Cláudia Servilha. Manual de metodologia da pesquisa no direito: São Paulo: Saraiva, 2004.

PAULO, Alexandre Ribas de. Origo gentis langobardorum: o primeiro texto escrito pelos germânicos da estirpe dos longobardos. In: Brathair 9 (2), 2009, p. 53. Disponível em: $<$ http://ppg.revistas.uema.br/index.php/brathair/article/view/496/416>. Acesso em 18 de junho de 2018.

ROUCHE, Michel. Alta idade média ocidental. In: ARIÈS, Philippe; DUBY, Georges (org.). História da vida privada: do império romano ao ano mil. São Paulo: Companhia das Letras, 2004, v.1. 
SESTAN, Ernesto. Stato e nazione nell'alto medioevo: ricerche sulle origine nazionali in francia, italia, germania. Napoli: Edizione Scientifiche Italiane, 1994.

TAMASSIA, Giovanni. Le fonti dell'editto di rotari. Pisa: Enrico Spoerri, 1889.

THOMPSON, Augusto F. G. Thompson. Escorço histórico do direito criminal luso-brasileiro. São Paulo: Revista dos Tribunais, 1976.

VEYNE, Paul. Como se escreve a história; Foucault revoluciona a história. Brasília: UNB, 1998.

WOLKMER, Antônio Carlos. História do direito no Brasil. Rio de Janeiro: Forense, 2007.

Trabalho recebido em 01 de outubro de 2018

Aceito em 14 de fevereiro de 2019 